Stratigraphic and Volcano-Tectonic Relations of Crater Flat Tuff and Some Older Volcanic Units, Nye County, Nevada

U.S. GEOLOGIGAL SURVEY PROFESSIONAL PAPER 1323

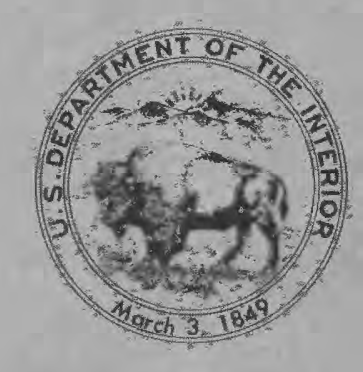




\section{Stratigraphic and Volcano-Tectonic Relations of Crater Flat Tuff and Some Older Volcanic Units, Nye County, Nevada}

By W. J. CARR, F. M. BYERS, JR., and PAUL P. ORKILD

U.S. GEOLOGICAL SURVEY PROFESSIONAL PAPER 1323

Prepared in cooperation with the U.S. Department of Energy

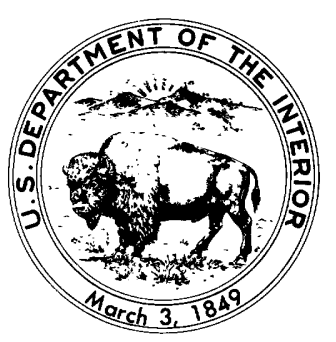




\section{DEPARTMENT OF THE INTERIOR \\ DONALD PAUL HODEL, Secretary}

\section{U.S. GEOLOGICAL SURVEY}

Dallas L. Peck, Director

\section{Library of Congress Cataloging in Publication Data}

Carr, Wilfred James, 1926-

Stratigraphic and volcano-tectonic relations of Crater Flat Tuff and some older volcanic units, Nye County, Nevada.

(Geological Survey professional paper ; 1323)

"Prepared in cooperation with the U.S. Department of Energy."

Bibliography: $p$.

Supt. of Docs. no.: I 19.16:1323

1. Volcanic ash, tuff, etc. 2. Geology, Stratigraphic-Miocene. 3. Petrology-Nevada-Nye County. I. Byers, F. M. (Frank M.), 1916- . II. Orkild, Paul P. III. United States. Dept. of Energy. IV. Title. V. Series.

QE461.C374 1985

$552^{\prime} .23$

$84-600019$

For sale by the Branch of Distribution

Books and Open-File Reports Section

U.S. Geological Survey

Federal Center

Box 25425

Denver, CO 80225 


\section{CONTENTS}

Page $\quad$ Page

Abstract $\ldots \ldots \ldots \ldots \ldots \ldots \ldots \ldots \ldots \ldots \ldots \ldots \ldots \ldots \ldots \ldots$

Introduction $\ldots \ldots \ldots \ldots \ldots \ldots \ldots$

General geologic relations . . . . . . . . . . . .

Stratigraphic relations . . . . . . . . . . .

Tuff of Yucca Flat ...................

Older ash-flow and bedded tuffs of drill hole USW-G1 .

Quartz latite ...................... .

Lithic Ridge Tuff and petrographically similar rhyolite lava

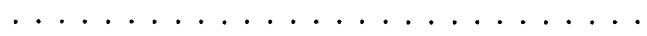

Rhyolite lava ...............

Lithic Ridge Tuff . . . . . . . . . . . .

Dacite intrusive and flow breccia . . . . . . . . .

Crater Flat Tuff and related lava ..........

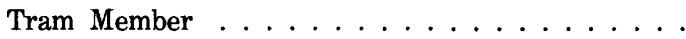

Type locality . . . . . . . . . . .

Drill hole USW-G1 . . . . . . . . . . . .

Distribution and thickness ..........

Stratigraphic relations-Continued

Crater Flat Tuff and related lava-Continued

Tram Member-Continued

Lithology and petrography .......... 17

Age and relation to other units . . . . . . . . 17

Bullfrog Member and petrographically similar lava. 18

Prow Pass Member . . . . . . . . . . . 18

Magnetic properties of Crater Flat Tuff and subjacent units 21

Calderas related to Crater Flat Tuff and subjacent units . 21

Geophysical evidence............... 21

Distribution and thickness of the tuffs ...... 22

Geologic relations ............... . . 24

Relation between Tram and Grouse Canyon Members 25

Pre-Crater Flat Tuff caldera . . . . . . . . . . . . 27

References .................. 27

\section{ILLUSTRATIONS}

FiguRE 1. Index map showing location of southwestern Nevada volcanic field and some associated calderas .......... 2

2. Chart showing stratigraphic relations of Crater Flat Tuff $\ldots \ldots \ldots \ldots \ldots$

3. Map showing distribution and thickness of tuff of Yucca Flat $\ldots \ldots \ldots \ldots$

4. Generalized cross section showing stratigraphic relations of tuff of Yucea Flat and Lithic Ridge Tuff at Lithic Ridge . . 6

5. Generalized cross section showing stratigraphic relations of tuff of Yucca Flat and Lithic Ridge Tuff at Area 16 tunnel

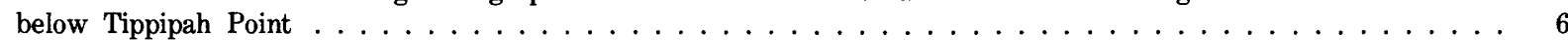

6. Chart showing modal ranges of outcrop samples of Crater Flat Tuff and associated volcanic units . . . . . . 8

7. Geologic cross section through drill holes USW-G1 and J-13 . . . . . . . . . . . . . . . . . . . . 9

8. Chart showing petrographic variation of Crater Flat Tuff and older units in drill hole USW-G1 . . . . . . . 10

9-12. Sketch maps showing:

9. Dacitic to rhyolitic lava flows and intrusive rocks of pre-Crater Flat Tuff age in the southwest Nevada Test

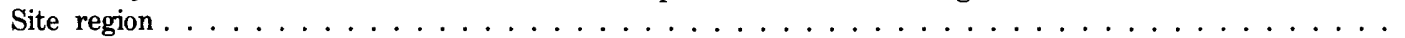

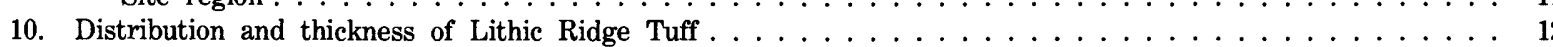

11. Distribution and thickness of Tram Member of Crater Flat Tuff . . . . . . . . . . . . . . . 15

12. Geologic relations of Tram Member of Crater Flat Tuff in Tram Ridge-Beatty Wash area . . . . . . . . 16

13. Geologic section sketch from northwest to southeast through Tram Ridge, showing relations of Tram Member to lava

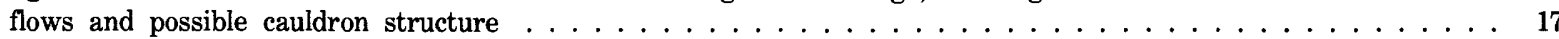

14. Map showing distribution and thickness of Bullfrog Member of Crater Flat Tuff $\ldots \ldots \ldots \ldots$

15. Map showing distribution and thickness of Prow Pass Member of Crater Flat Tuff . . . . . . . . . . . . . 20

16. Bouguer gravity map of the NTS region, showing the regional gravity low associated with several caldera complexes . 23

17. Aeromagnetic map of southern Crater Flat area, showing caldera boundary and buried resurgent dome of the Bullfrog

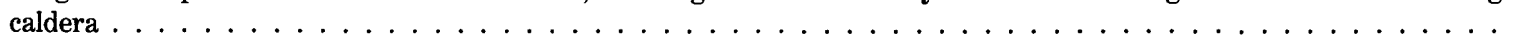

18. Sketch map of the southwestern NTS region, showing the relation of the Crater Flat-Prospector Pass caldera complex

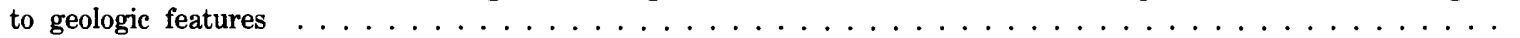

\section{TABLE}

TABLE 1. Remanent magnetic directions of Crater Flat Tuff, Lithic Ridge Tuff, and tuff of Yucca Flat . . . . . . . . 22 



\title{
STRATIGRAPHIC AND VOLCANO-TECTONIC RELATIONS OF CRATER FLAT TUFF AND SOME OLDER VOLCANIC UNITS, NYE COUNTY, NEVADA
}

\author{
By W. J. Carr, F. M. Byers, Jr., and PAul P. Orkild
}

\begin{abstract}
The Crater Flat Tuff is herein revised to include a newly recognized lowest unit, the Tram Member, exposed at scattered localities in the southwest Nevada Test Site region, and in several drill holes in the Yucca Mountain area. The overlying Bullfrog and Prow Pass Members are well exposed at the type locality of the formation near the southeast edge of Crater Flat, just north of U.S. Highway 95. In previous work, the Tram Member was thought to be the Bullfrog Member, and therefore was shown as Bullfrog or as undifferentiated Crater Flat Tuff on published maps. The revised Crater Flat Tuff is stratigraphically below the Topopah Spring Member of the Paintbrush Tuff and above the Grouse Canyon Member of the Belted Range Tuff and is approximately $13.6 \mathrm{~m} . \mathrm{y}$. old.

Drill holes on Yucca Mountain and near Fortymile Wash penetrate all three members of the Crater Flat as well as an underlying quartzpoor unit, which is herein defined as the Lithic Ridge Tuff from exposures on Lithic Ridge near the head of Topopah Wash. In outcrops between Calico Hills and Yucca Flat, the Lithic Ridge Tuff overlies a Bullfrog-like unit of reverse magnetic polarity that probably correlates with a widespread unit around and under Yucea Flat, referred to previously as Crater Flat Tuff. This unit is here informally designated as the tuff of Yucca Flat. Although older, it may be genetically related to the Crater Flat Tuff.

Although the rocks are poorly exposed, geophysical and geologic evidence to date suggests that (1) the source of the Crater Flat Tuff is a caldera complex in the Crater Flat area between Yucca Mountain and Bare Mountain, and (2) there are at least two cauldrons within this complex-one probably associated with eruption of the Tram, the other with the Bullfrog and Prow Pass Members. The complex is named the Crater Flat-Prospector Pass caldera complex. The northern part of the Yucca Mountain area is suggested as the general location of the source of pre-Crater Flat tuffs, but a caldera related to the Lithic Ridge Tuff has not been specifically identified.
\end{abstract}

\section{INTRODUCTION}

The U.S. Geological Survey has conducted research in support of the Nevada Nuclear Waste Storage Investigations of the U.S. Department of Energy in the southwest Nevada Test Site (NTS) region since 1977. From 1978 to 1982, regional geophysical investigations, geologic mapping, regional geologic reconnaissance, and data from several drill holes, principally on Yucca Mountain (fig. 1), have defined a thick Miocene volcanic sequence under Yucca Mountain and Crater Flat. In the lower part of the sequence, below the Crater Flat Tuff (Byers and others, 1976a and 1976b), are several volcanic units that were unrecognized prior to 1978. Some of these units crop out outside the deep volcanic subsidence area beneath Crater Flat and northern Yucca Mountain, and have been correlated with the subsurface units by petrographic methods. The purposes of this paper are to revise the stratigraphic position and content of the Crater Flat Tuff, to suggest its volcano-tectonic setting, and to describe the older volcanic units in order to better define the subsurface structure in the southwestern NTS area.

The authors acknowledge valuable support from colleagues in the U.S. Geological Survey, especially Gordon D. Bath and J. G. Rosenbaum, who provided magnetic polarity determinations of the tuffs. Margaret Baldwin, of Fenix and Scisson, Inc., Mercury, Nev., made a number of determinations of magnetic characteristics of the units. A geologic map of the southwestern NTS area compiled by Florian Maldonado (1985) uses informal nomenclature for the new stratigraphic units established formally in this report. Extensive studies of geologic relations in the adjoining Bare Mountain quadrangle by two of the authors of this report, Orkild and Carr, and by P. W. Lipman and W. D. Quinlivan have been essential in establishing stratigraphic relations of the ash-flow tuffs and intercalated lavas. Detailed lithologic logs of drill hole USW-G1 by Spengler and others (1981), of drill hole USW-G2 by Florian Maldonado and S. L. Koether (written commun., 1982), and of drill holes USW-G3 and USW-H6 by R. B. Scott (written commun., 1982) also provided important data for this report. 


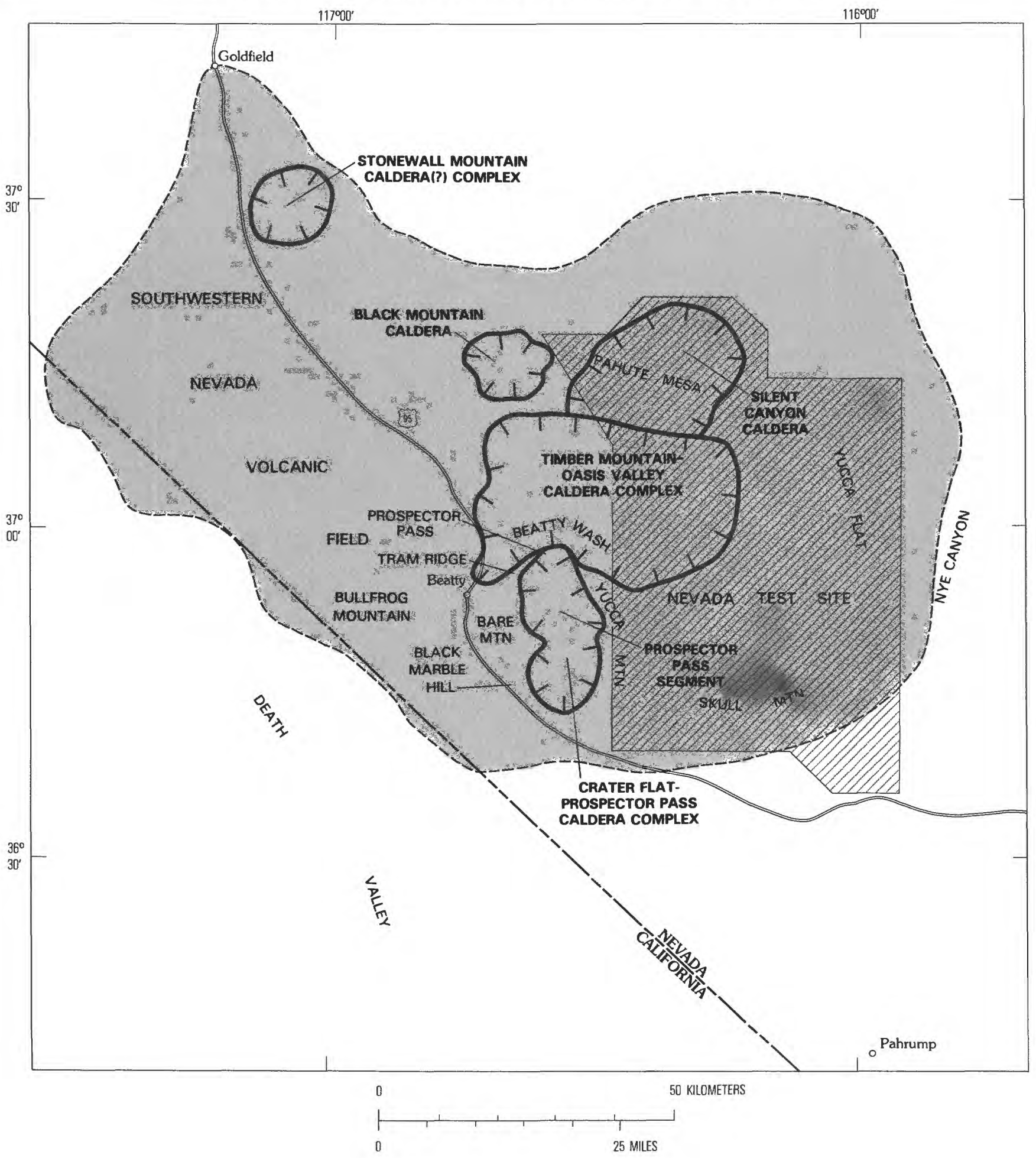

FIGURE 1.-Locations of southwestern Nevada volcanic field (shaded) and some associated calderas. 


\section{GENERAL GEOLOGIC RELATIONS}

The western part of the NTS is within the southwestern Nevada volcanic field (Christiansen and others, 1965; Byers and others, 1976b; Christiansen and others, 1977), which consists of a thick sequence of Tertiary silicic volcanic rocks about 7-15 m.y. (million years) old, roughly centered around the Timber Mountain-Oasis Valley and Silent Canyon caldera complexes (Noble and others, 1968). The field extends from east of Yucca Flat westward to about the California-Nevada State line, and from approximately Skull Mountain and U.S. Highway 95 northwestward to the vicinity of Goldfield. The regional geologic setting is outlined by Christiansen and others (1977, p. 943-946).

The volcanic stratigraphic units defined in this paper underlie the extensive, well-exposed ash-flow sheets of the Paintbrush and Timber Mountain Tuffs (fig. 2), which originated from the Timber Mountain-Oasis Valley caldera complex described by Byers and others $(1976 \mathrm{a}, \mathrm{b})$. The older, pre-Paintbrush volcanic rocks were not given the intensive study that the younger, better exposed ones received (Byers and others, 1976b). The Crater Flat Tuff, then thought to consist of only the Bullfrog and Prow Pass Members, was recognized to be widespread in the southwestern part of the NTS and the adjacent area to the west (Byers and others, 1976b, fig. 4). Recent geologic and geophysical work and the results of deep drilling on Yucca Mountain (fig. 1) now lead us to believe that an important volcano-tectonic depression, which may be more than $3,000 \mathrm{~m}(10,000 \mathrm{ft})$ deep and may include several buried calderas, underlies Crater Flat and part of Yucca Mountain (Snyder and Carr, 1982).

The revised Crater Flat Tuff is now known to be younger than the Grouse Canyon Member of the Belted Range Tuff (fig. 2), and the pre-Grouse Canyon unit that was previously correlated with the Bullfrog Member in the Yucca Flat and Pahute Mesa areas of the northern NTS is reduced to informal status and here called the tuff of Yucca Flat.

The period of intense volcanism discussed in this report spans about $1.5 \mathrm{~m} . \mathrm{y}$., roughly between 14.5 and 13 m.y. ago (fig. 2). Existing age control and the number of volcanic units indicate that major eruptive episodes occurred, on the average, about every 100,000 years during this period.

\section{STRATIGRAPHIC RELATIONS}

\section{TUFF OF YUCGA FLAT}

The tuff of Yucca Flat is here designated as an informal unit consisting of a quartz-bearing ash-flow sheet present around and beneath Yucca Flat (fig. 3). The unit may be an early precursor to the members of the Crater Flat Tuff, as it closely resembles the Bullfrog Member petrographically, but it has not been found in southwestern NTS or in drill holes at Yucca Mountain. The tuff of Yucca Flat was erroneously correlated with the Crater Flat Tuff (Byers and others, 1976b, p. 8-9; Dixon and others, 1976, p. A50). It is a useful stratigraphic marker in the subsurface of east-central Yucca Flat, Pahute Mesa, and Rainier Mesa (Orkild and others, 1968), and crops out on both the east and west sides of Yucca Flat, as well as to the southeast in Scarp and Nye Canyons (fig. 3).

The tuff of Yucca Flat occurs stratigraphically between tunnel beds 1 and 2 in east-central Yucca Flat (Dixon and others, 1976) and in the Rainier Mesa tunnel area (Steele and Fairer, 1978; Fairer and Townsend, 1979). Tunnel beds 1 through 4 (Gibbons and others, 1963) occur stratigraphically between the Redrock Valley Tuff (fig. 2), which has a potassiurn-argon age of $15.7 \mathrm{~m} . y$. , and ash-fall beds of the Grouse Canyon Member of the Belted Range Tuff of $13.8 \mathrm{~m} . \mathrm{y}$. age $^{1}$ (Gibbons and others, 1963; Marvin and others, 1970; Byers and others, 1976b). The oldest peralkaline ashfall beds in tunnel bed 2 are believed to correlate with the earliest peralkaline lava, the rhyolite of Kawich Valley, dated at 14.8 m.y. (Marvin and others, 1970). Thus, from available data, the age of the tuff of Yucca Flat is probably about 15.0 m.y.

The stratigraphic position of the tuff of Yucca Flat is shown on figures 2, 4, and 5. At Lithic Ridge (figs. 3 and 4), the tuff of Yucca Flat is overlain by a local quartz latitic tuff and the Lithic Ridge Tuff. Below Tippipah Point (fig. 5), the tuff of Yucca Flat rests on the Redrock Valley Tuff and is overlain successively by a quartz-sanidine tuff, not recognized elsewhere, the

\footnotetext{
${ }^{1} \mathrm{~A} \mathrm{~K}$-Ar age determination of $\mathbf{1 3 . 6 \pm 0 . 5} \mathrm{m} . \mathrm{y}$. has been made on alkali feldspar from a boulder of porphyritic welded tuff of the Grouse Canyon collected from beneath the Crater Flat Tuff type locality at U.S. Highway 95 (R. F. Marvin, written commun., 19130), suggesting that an average of 13.7 m.y. may be a better age for the Grouse Canyon.
} 
CRATER FLAT TUFF AND OLDER VOLCANIC UNITS, NYE COUNTY, NEVADA

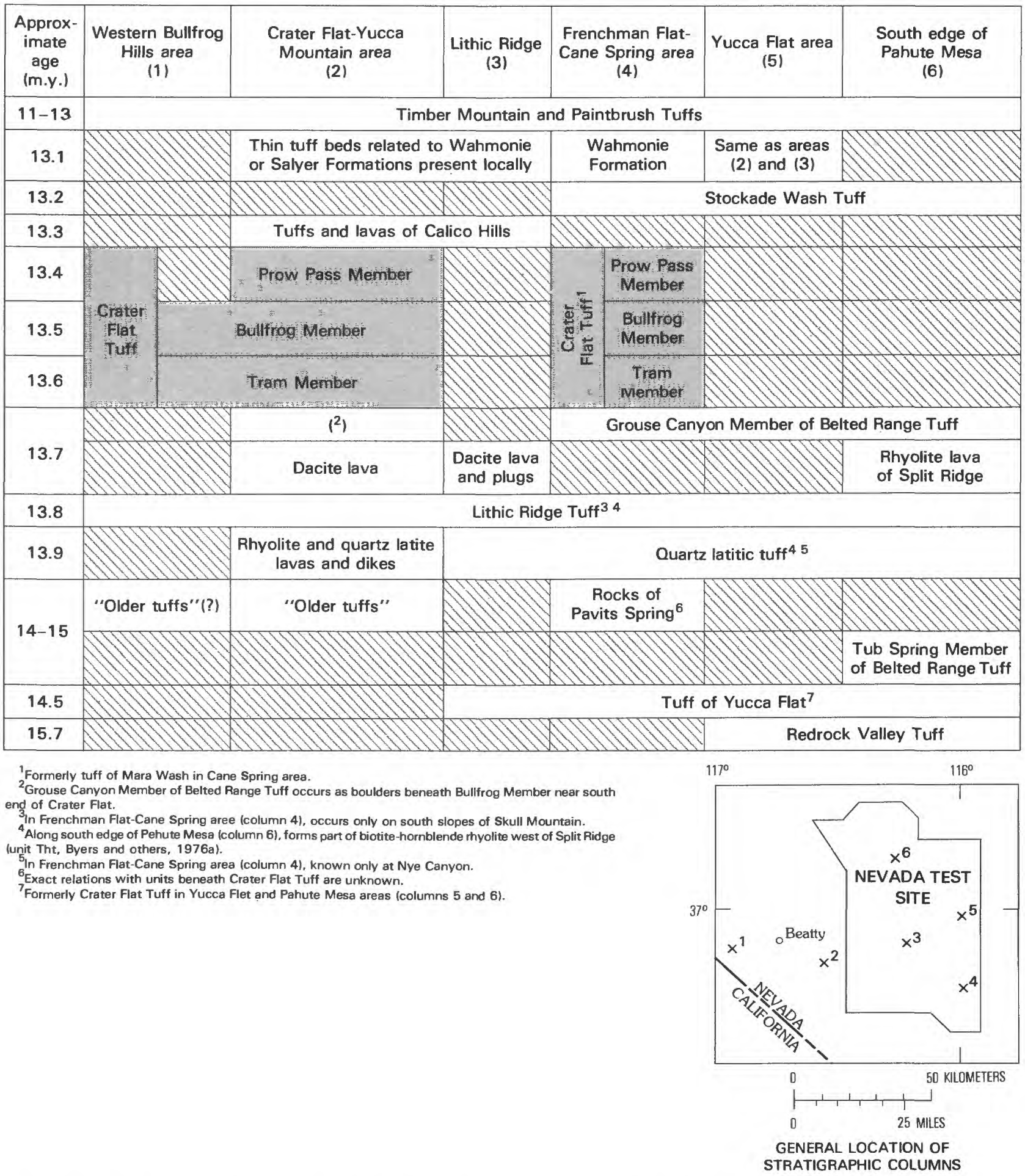

FigurE 2.-Stratigraphic relations of Crater Flat Tuff and associated units in Nevada Test Site region. Numbers in column heads refer to localities shown on inset.

Lithic Ridge Tuff, the Grouse Canyon Member datum, bedded tuffs, and the Paintbrush Tuff, which forms Tippipah Point. Ash-fall tuff of the Grouse Canyon is present between the Lithic Ridge Tuff and the overlying Paintbrush Tuff about a mile north of the section below Tippipah Point. 


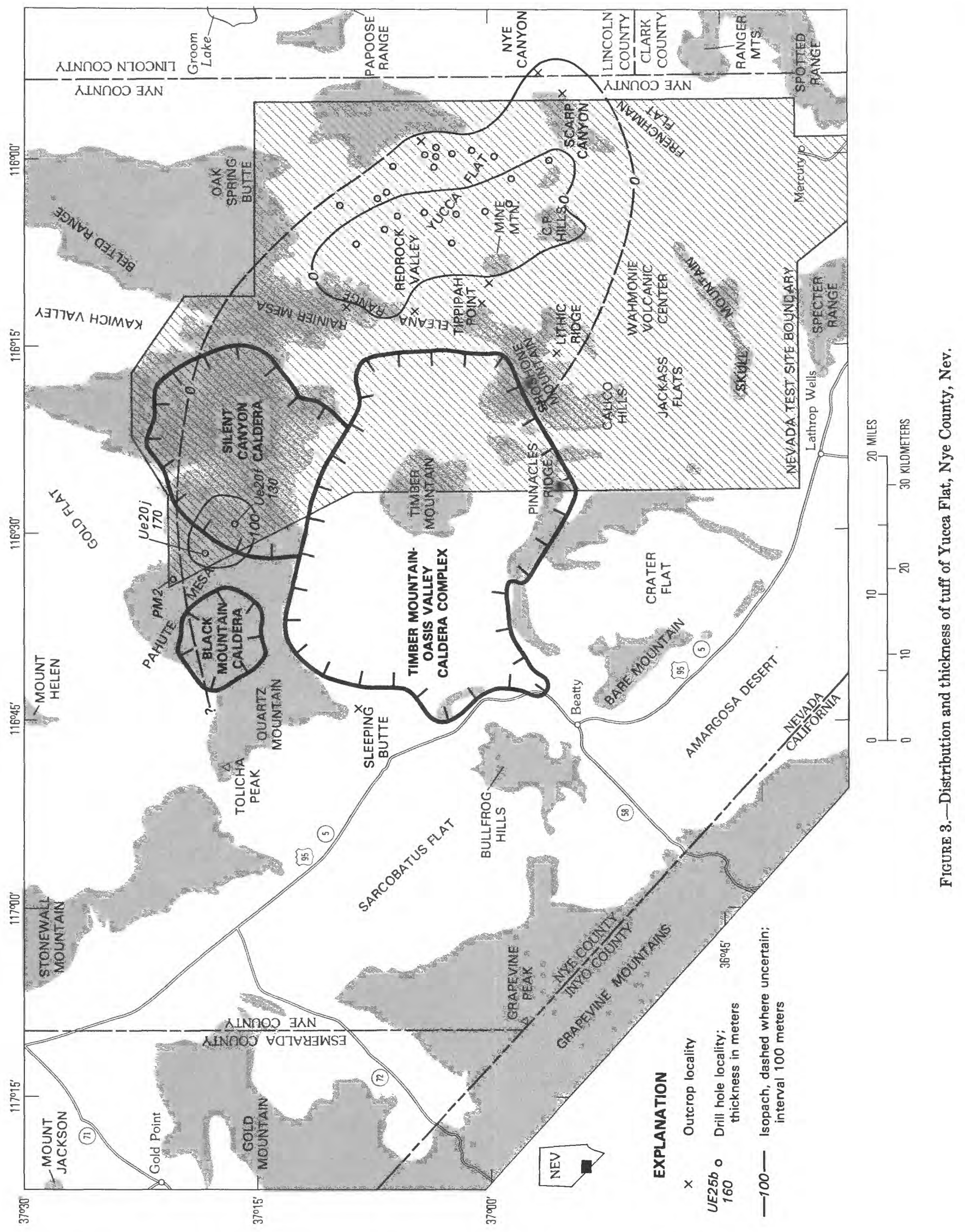




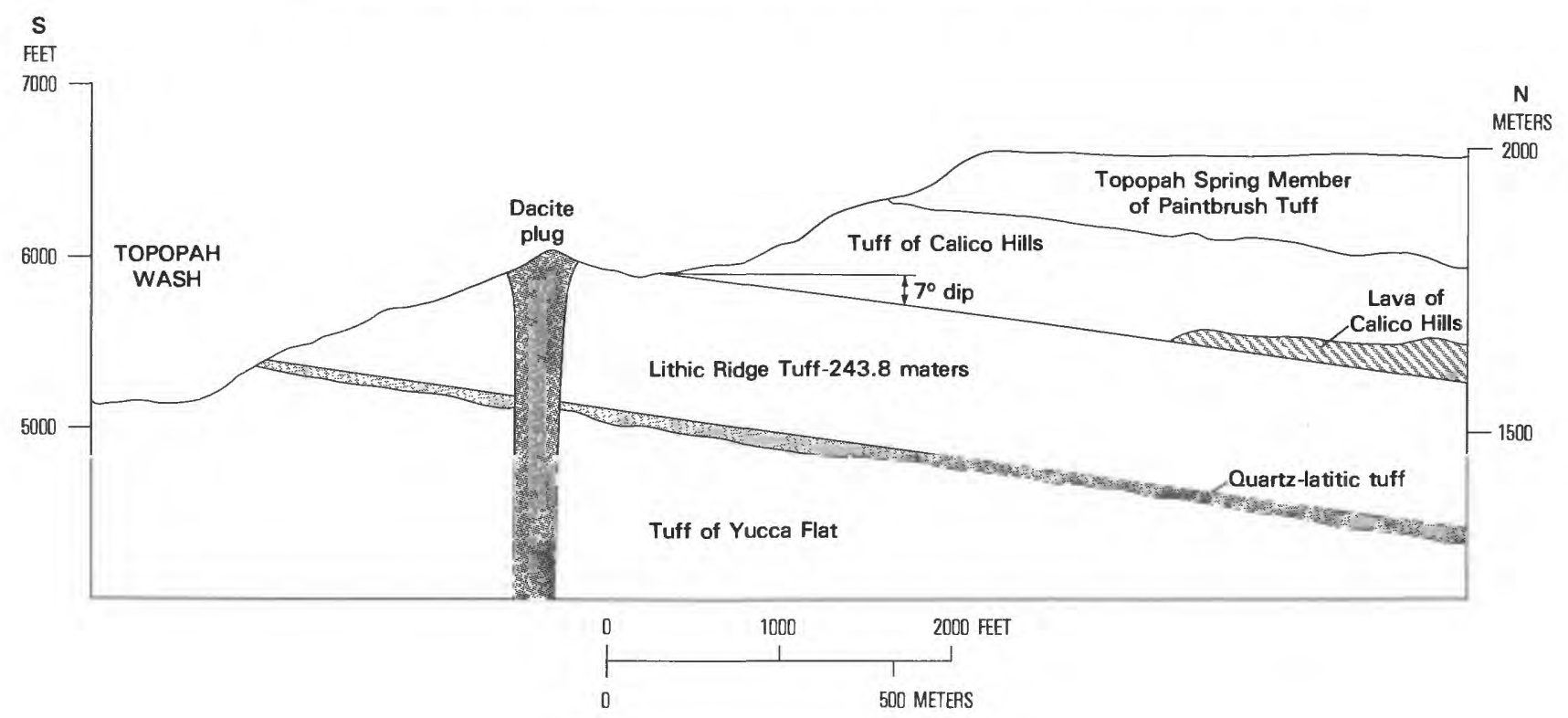

FIGURE 4. - Stratigraphic relations of tuff of Yucca Flat and Lithic Ridge Tuff at Lithic Ridge.
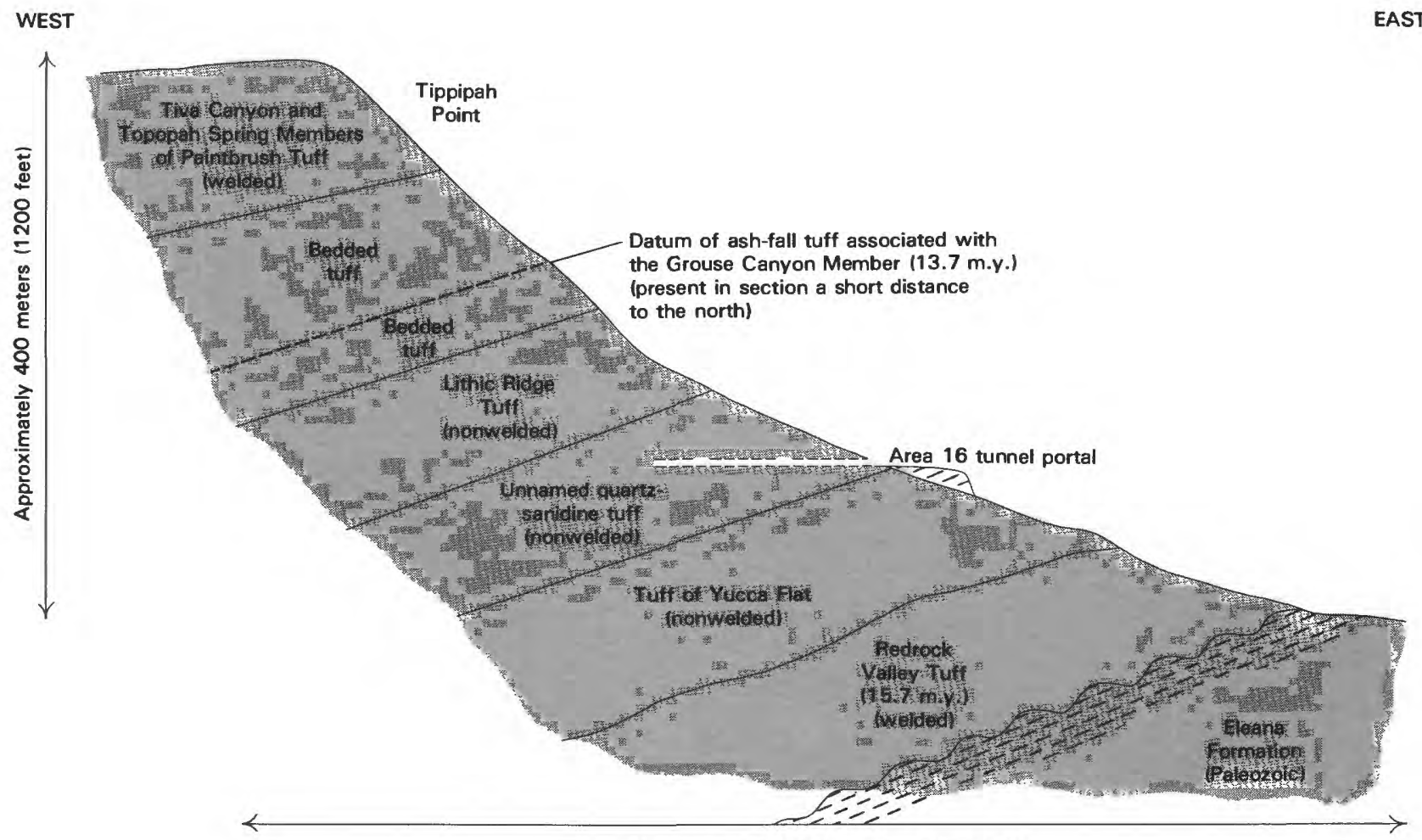

Approximately 1200 meters $(3600$ feet)

FIGURE 5. - Stratigraphic relations of tuff of Yucca Flat and Lithic Ridge Tuff at Area 16 tunnel below Tippipah Point. 
Four successive ash falls at Nye Canyon, at the eastern border of the Nevada Test Site (fig. 3), are apparently petrographically related to the tuff of Yucca Flat, the quartz latitic units, the Grouse Canyon Member, and the Bullfrog Member, respectively. At Scarp Canyon (fig. 3), the tuff of Yucca Flat is interbedded with tuffaceous sediments of the rocks of Pavits Spring (Poole, Elston, and Carr, 1965; Poole, Carr, and Elston, 1965), about $45 \mathrm{~m}$ (150 ft) stratigraphically below the base of the Bullfrog Member of the Crater Flat Tuff. At Pahute Mesa, in drill holes UE20j and UE20f (fig. 3), the tuff of Yucca Flat underlies the Tub Spring Member of the Belted Range Tuff and the tuff of Tolicha Peak, respectively (Byers and others, 1976b, p. 14-15). In drill holes of eastern Yucca Flat, the tuff of Yucca Flat also underlies the Tub Spring and the tuff of Tolicha Peak, which are included in tunnel bed 2. Thus, the tuff of Yucca Flat has the same stratigraphic relations over a large area extending from Scarp and Nye Canyons northwestward beneath Rainier and Pahute Mesas.

The tuff of Yucca Flat consists of zeolitic and nonwelded ash-flow tuff in the Yucca Flat area, but is moderately welded and devitrified at Lithic Ridge. At Nye Canyon, the correlative ash fall is vitric. The tuff of Yucca Flat petrographically resembles the Bullfrog Member of the Crater Flat Tuff but differs from it by having (1) few if any resorbed ("wormy") quartz phenocrysts, (2) spherulitic rhyolite lithic fragments, particularly where xenoliths are abundant, and (3) a general lack of pilotaxitic quartz latitic to dacitic lava fragments. Apparently the pilotaxitic lavas, intrusives, and minor tuffs of intermediate composition postdate the tuff of Yucca Flat (fig. 6). The spherulitic rhyolitic tuff or lava fragments, as seen under $100 \times$ magnification, contain very thin (a few microns or less), brown, filamentous mafic crystallites resembling hair. These fragments very closely resemble those seen in the older tuffs of drill hole USW-G1 and in the Lithic Ridge Tuff and are similar to those in the Tram Member of the Crater Flat Tuff, but they have not been noted in other ash-flow tuffs rich in lithic fragments, such as those of Area 20 for example (Byers and others, 1976b). The occurrence of similar fragments in several stratigraphic units suggests a common source area, not only for the fragments but perhaps for the tuffs as well. The principal reasons for placing the tuff of Yucca Flat stratigraphically beneath the older tuffs at Yucca Mountain are its content of silicic phenocryst assemblages and its lack of intermediate-composition lithic fragments, which are common in other pre-Crater Flat tuffs.
It should be noted that pre-Grouse Canyon ash-flow tuffs of the Sleeping Butte area (fig. 3), mapped by Paul P. Orkild and K. A. Sargent (written commun., 1971), are probably not related to the tuff of Yucca Flat and the Crater Flat Tuff as intimated by Byers and others $(1976 \mathrm{~b}, \mathrm{p} .15)$. The lithic fragments are different in those rocks, and the tuff at Sleeping Butte that resembles the tuff of Yucca Flat and the Bullfrog Member contains common sphene in every thin section examined. Further study is necessary to determine the relationship, if any, of the tuffs in the Sleeping Butte area to the Crater Flat or older units.

\section{OLDER ASH-FLOW AND BEDDED TUFFS OF DRILL HOLE USW-G1}

These tuffs were penetrated beneath Yucca Mountain in drill hole USW-G1 (figs. 7 and 8) from a depth of $1,508 \mathrm{~m}(4,946.4 \mathrm{ft})$ to $1,829 \mathrm{~m}(6,000 \mathrm{ft})$, the bottom of the hole. The sequence is described in detail in the drill hole report by Spengler and others (1981), and only the principal petrographic features are mentioned here. The older tuffs of USW-G1, with one or two possible exceptions, are known only in the subsurface under Yucca Mountain. Spengler and others (1981) have divided the older tuffs into three units from the top down: unit A, a thick, quartz-rich ash-flow tuff (fig. 8); unit B, a transitional unit of several thin ash flows in which quartz decreases and plagioclase phenocrysts increase downward; and unit $\mathrm{C}$, which consists of several ash-flow tuffs separated by reworked tuffaceous sediments and which contains minor alkali feldspar and quartz but relatively abundant plagioclase and mafic phenocrysts (fig. 8). The older tuffs in hole USW-G1 are hydrothermally altered, but the alteration has not completely erased the primary minerals or their pseudomorphs.

Certain significant petrographic features of these older tuffs are noteworthy. The lowest unit, C, from $1,656 \mathrm{~m}(5,434 \mathrm{ft})$ to the bottom of the hole at 1,829 m $(6,000 \mathrm{ft})$ contains several ash-flow tuffs characterized by relatively abundant plagioclase and lesser amounts of biotite, hornblende, and clinopyroxene, in decreasing order of abundance. Pilotaxitic lava lithics of quartz latitic composition predominate in the lithic assemblages of unit $\mathrm{C}$, suggesting a possible coincidence of eruptive source areas of quartz latite lava and ash-flow tuff.

The transition unit, B, has less quartz and alkali feldspar than unit A, but also has a higher proportion of pilotaxitic lava lithic fragments of intermediate composition. 

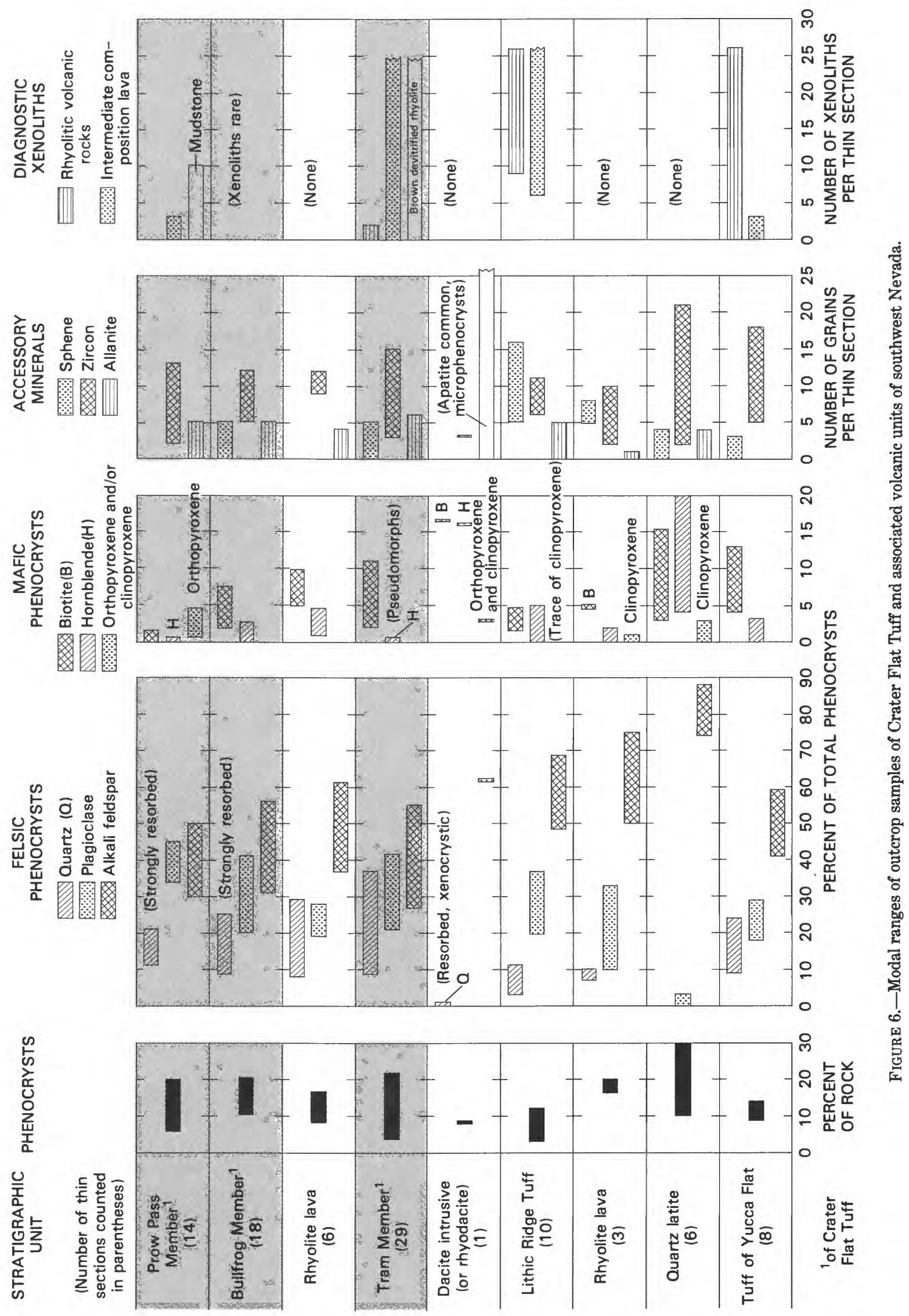

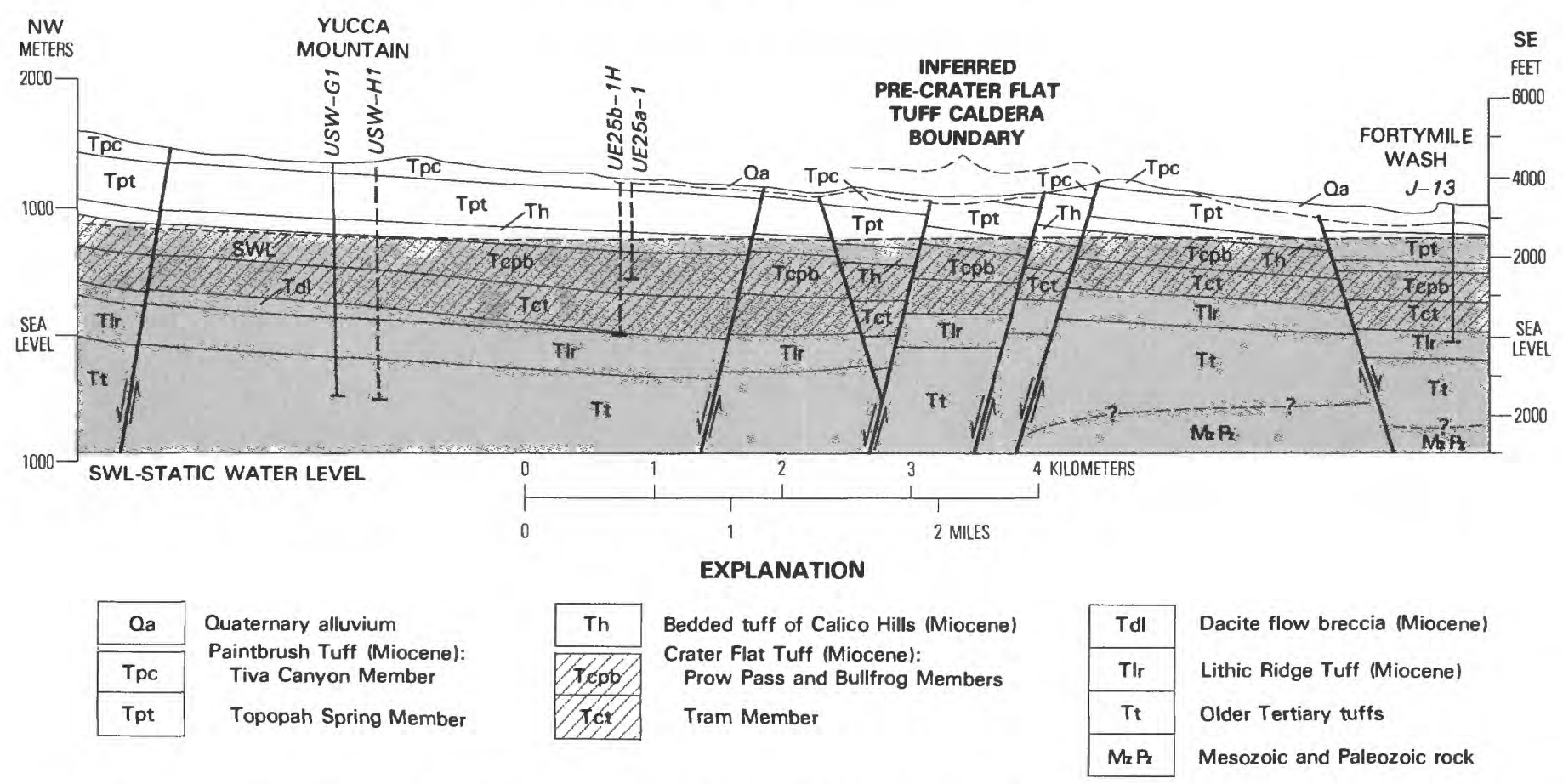

FIGURE 7.-Geologic cross section between drill holes USW-G1 and J-13 in the Yucca Mountain area, Nye County, Nev. Shaded area is below static water level.

Unit A is a simple cooling unit of silicic, quartz-rich ash-flow tuffs, very similar to the superjacent Tram Member of the Crater Flat Tuff (fig. 8). Unit A, however, has fewer lithic fragments than parts of the Tram, and among these fragments, spherulitic rhyolite is dominant and pilotaxitic lava of intermediate composition is subordinate. The Tram Member has the opposite lithic abundances. The lithic content is the best means of distinguishing this unit from the Tram. Also, mafic phenocrysts are slightly less abundant in unit A than in the Tram.

\section{QUARTZ LATITE}

The volcanic rocks included under this heading underlie the Tram Member and the Lithic Ridge Tuff and are widespread at this general stratigraphic position. As mentioned, these rocks may have been a source of the pilotaxitic xenoliths of unit $\mathrm{C}$ in the older ash-flow tuffs of drill hole USW-G1, as well as those in the Lithic Ridge Tuff and the Tram Member of the Crater Flat Tuff. The quartz latite unit is mainly lava, but quartz latitic ash-flow tuff, possibly correlative with the lavas, occurs beneath the Lithic Ridge Tuff at Lithic Ridge, and similar ash fall is found at Nye Canyon and in the subsurface beneath Yucca Flat in unit 2 of the tunnel beds (Gibbons and others, 1963).

Quartz latite lava is exposed under the Lithic Ridge Tuff at Bullfrog Mountain (fig. 1) and at Tram Ridge near Beatty Wash (fig. 9). A similar lava flow also is exposed above a tuffaceous sedimentary sequence south of Black Marble Hill, at the south end of Bare Mountain, near U.S. Highway 95 (figs. 1 and 9). Quartz latite dikes in the eastern part of Bare Mountain, adjacent to Crater Flat, gave the same potassium-argon age (13.9 m.y.; R. F. Marvin, written commun., 1980) as the pre-Lithic Ridge Tuff lava flows in Beatty Wash.

The phenocryst assemblage of the quartz latite lava is characterized by about 80 percent plagioclase and 20 percent mafic phenocrysts, which consist mainly of biotite and hornblende, with or without clinopyroxene (fig. 6). Zircon is present in all specimens and apatite is common. A few microphenocrysts of allanite and sphene occur in some specimens. Chemical analyses may show that some of these rocks are rhyolites, but their phenocryst assemblage is sufficiently mafic to warrant the name quartz latite, in order to distinguish these rocks from the more silicic rhyolites containing quartz and alkali feldspar phenocrysts.

\section{LITHIC RIDGE TUFF AND PETROGRAPHICALLY SIMILAR RHYOLITE LAVA RHYOLITE LAVA}

The rhyolite lava (fig. 6) and the Lithic Ridge Tuff are discussed under the same heading in order to emphasize their petrographic similarity and probable 


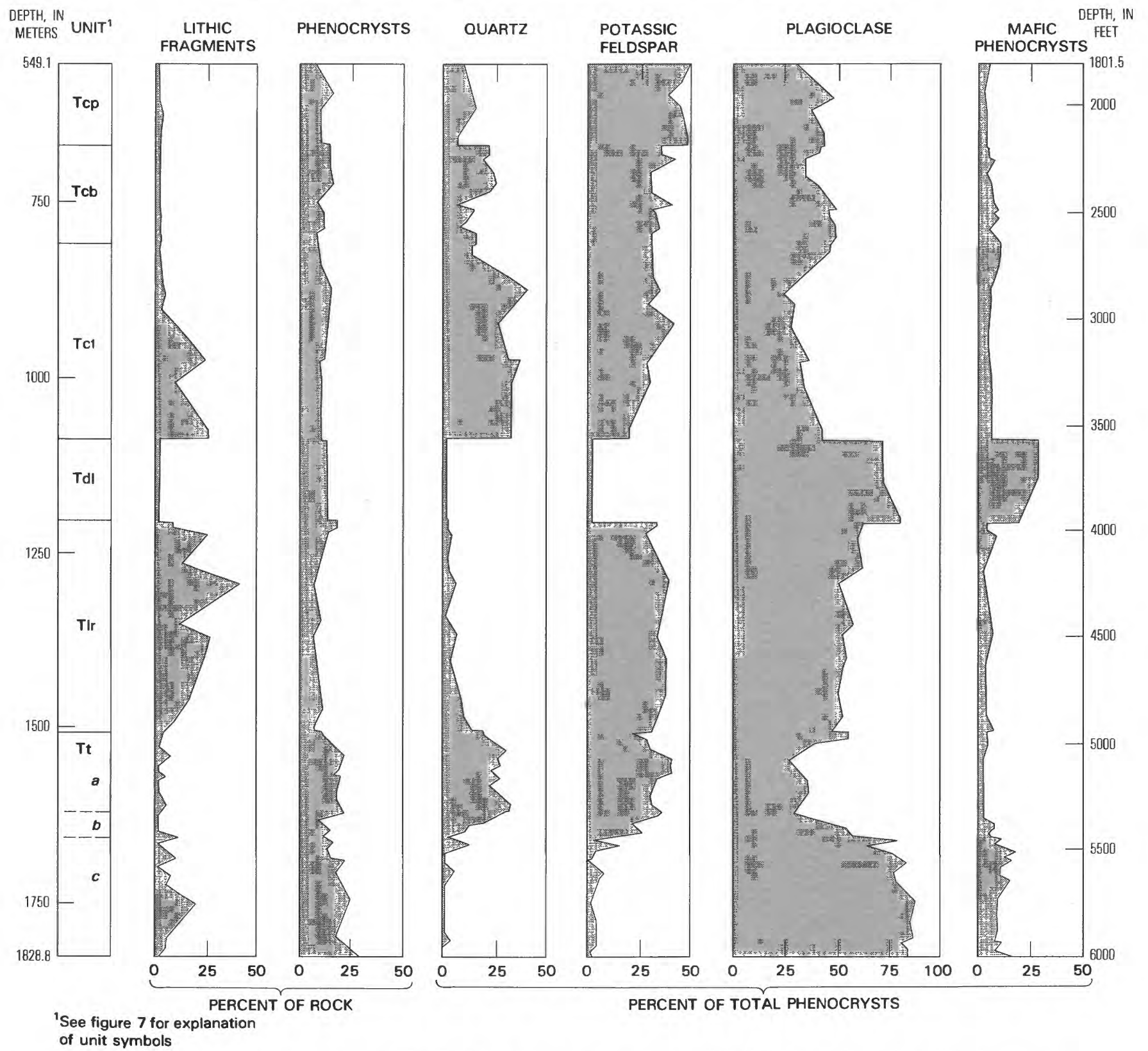

FIGURE 8.-Petrographic variation of Crater Flat Tuff and older units in drill hole USW-G1 on Yucca Mountain, Nye County, Nev.

genetic association. Similar associations between lava and ash-flow tuffs are common within the Paintbrush and Timber Mountain Tuffs (Byers and others, 1976b, p. 24, 25, 51-52, 61). The rhyolite lava that resembles the Lithic Ridge Tuff is exposed only in a small area at Tram Ridge, near Beatty Wash, where the rhyolite overlies a quartz latite lava (fig. 9). The rhyolite lava is separated from the overlying Lithic Ridge Tuff by several meters of bedded ash-fall tuff. Biotite from both lavas yielded the same age: 13.9 m.y. (R. F. Marvin, written commun., 1980).

The rhyolite lava is characterized by a plagioclase-alkali feldspar ratio of about $2: 1$, like that of the Lithic
Ridge, by small amounts of quartz and biotite, and by rare hornblende. As in the Lithic Ridge Tuff, at least five microphenocrysts of sphene occur in each thin section of all three specimens examined.

\section{LITHIC RIDGE TUFF}

The Lithic Ridge Tuff is here named after the excellent exposure at Lithic Ridge ${ }^{2}$ (figs. 4 and 10), its type locality, where approximately $250 \mathrm{~m}(800 \mathrm{ft})$ of non-

${ }^{24}$ Lithic Ridge" is a newly established geographic name that is not shown on older topographic maps of the area. 


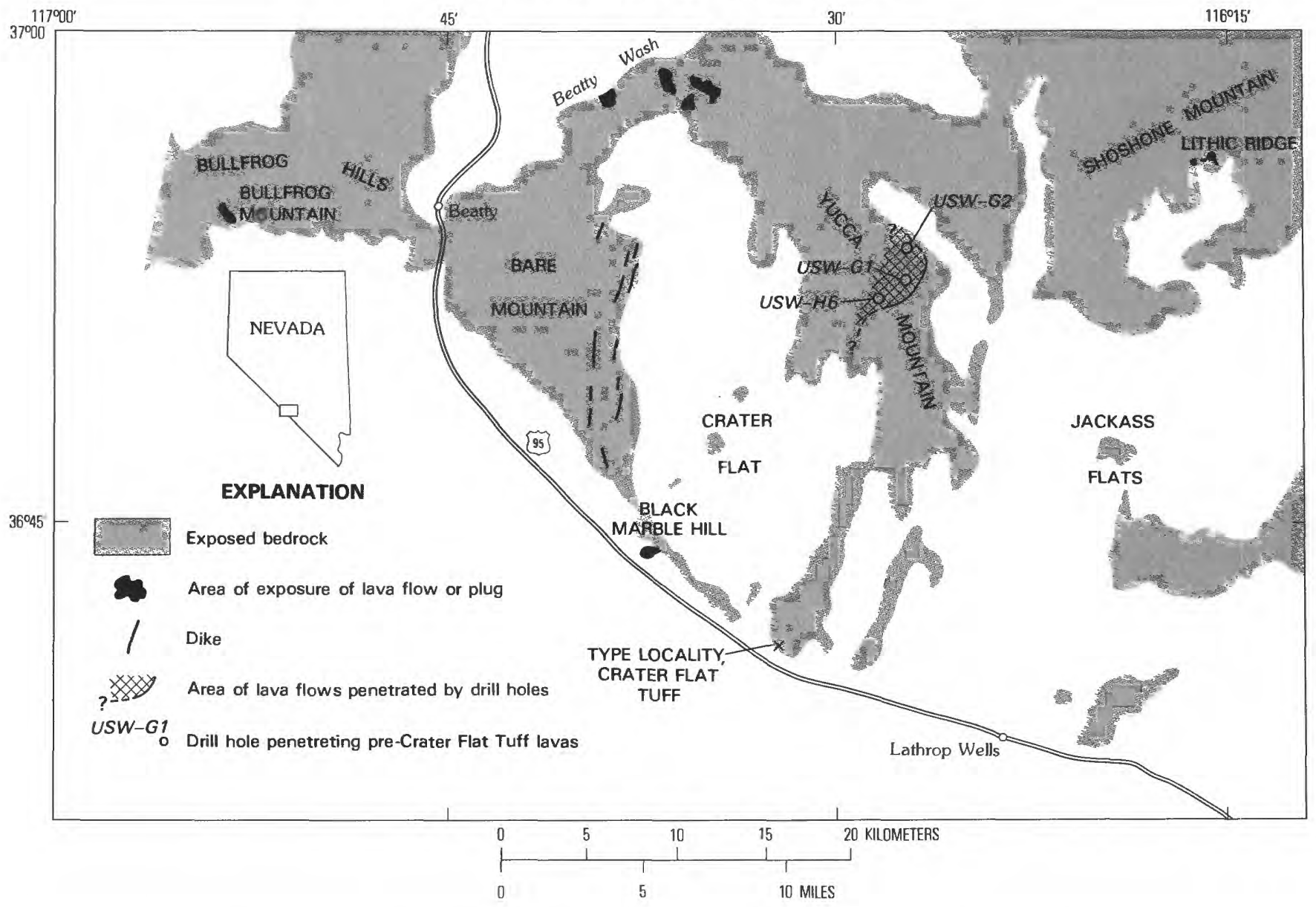

FIGURE 9. - Sketch map of dacitic to rhyolitic lava flows and intrusive rocks of pre-Crater Flat Tuff age in the southwestern Nevada Test Site region.

welded to partially welded tuff is exposed. Lithic Ridge is located $1 \mathrm{~km}$ southeast of Topopah Spring in the Topopah Spring 71/2-minute quadrangle. The Lithic Ridge Tuff is one of the most extensive of the units discussed in this report, as shown on figure 10. Furthermore, it is the only unit older than the Paintbrush Tuff known to occur in both the northern and southern parts of the NTS region. The unit was completely penetrated at depths below about $1,200 \mathrm{~m}(4,000 \mathrm{ft})$ in drill holes USW-G1, USW-H1, USW-G2, and USW-G3, where thicknesses of $303,274,207$, and $304 \mathrm{~m}(994,899,679$, and $997 \mathrm{ft}$ ) are reported (fig. 10; Spengler and others, 1981; Florian Maldonado, written commun., 1982; and R. B. Scott, written commun., 1982). The upper part of the unit was penetrated in drill hole UE25b-1 at

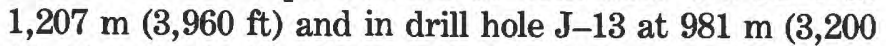
ft) (fig. 7). At Bullfrog Mountain (fig. 1), about $70 \mathrm{~m}$ (230 ft) of hydrothermally altered Lithic Ridge Tuff dips northeastward just above the shaft of the Bullfrog Mine, where the unit was formerly thought to consti- tute the lower part of the Bullfrog Member (Byers and others, 1976b).

The Lithic Ridge Tuff crops out in a small area at the southern edge of Pahute Mesa, in the canyon between Blacktop Buttes and Split Ridge (fig. 10). The unit is overlapped by younger tuffs, so its base is not exposed and its total thickness is unknown at this locality, but it occurs stratigraphically above quartz-latitic tuff, which rests on the Tub Spring Member of the Belted Range Tuff, and below the rhyolite lavas of Split Ridge, which are beneath the Grouse Canyon Member. This locality is just southeast of the edge of the Silent Canyon caldera, the source area of the Tub Spring and Grouse Canyon Members of the Belted Range Tuff. The unit could be much thicker to the northwest within the collapse area of the Silent Canyon caldera, which is related to the Tub Spring Member.

At the type locality of the Lithic Ridge (figs. 4 and 10), the unit was originally included in the lower part of the tuff of Calico Hills (Orkild and O'Connor, 1970; 


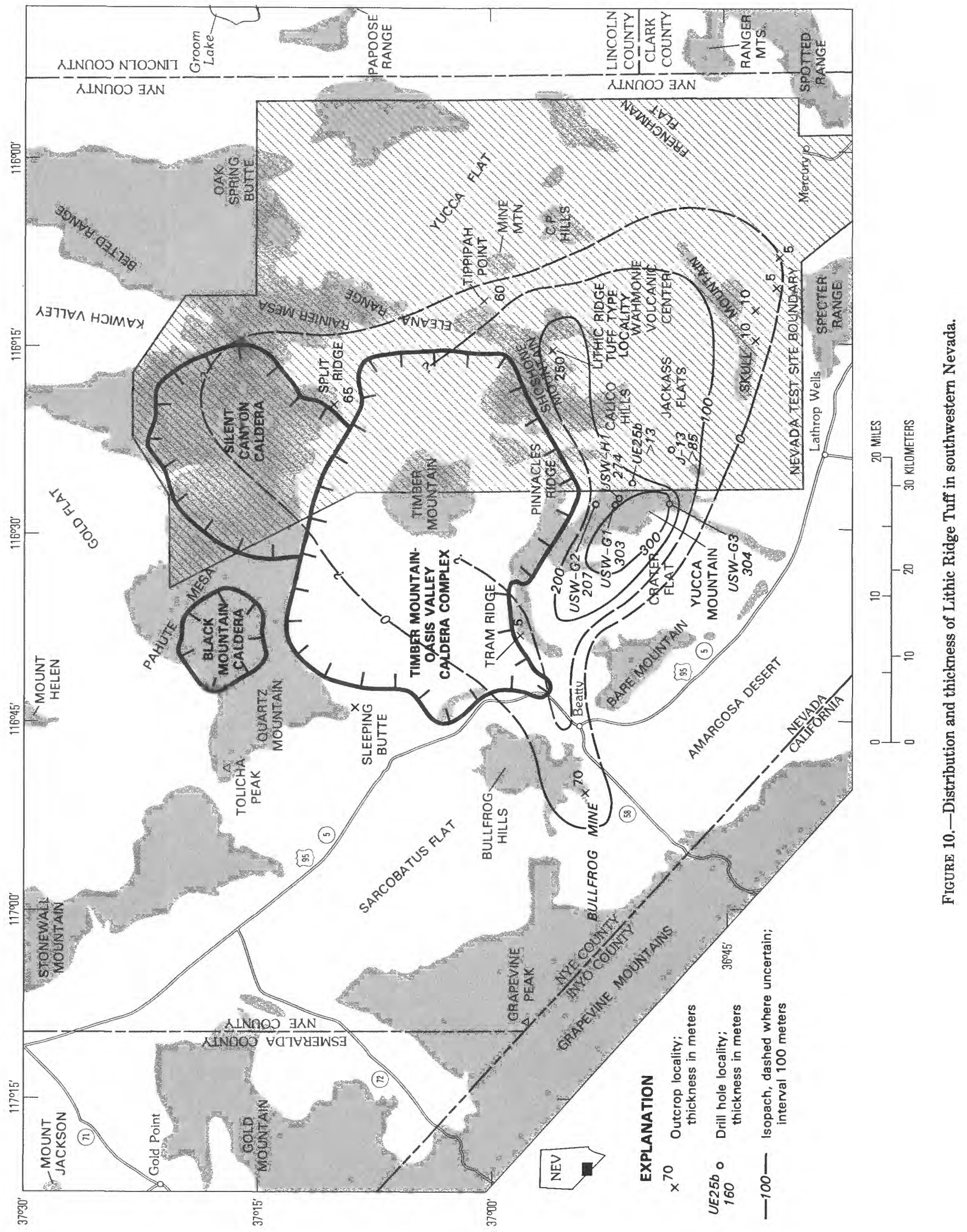


Byers and others, 1976a). At Lithic Ridge the unit rests on a thin, quartz-latitic ash-flow tuff that is similar petrographically both to the tuff penetrated near the bottom of USW-G1 at $1,829 \mathrm{~m}(6,000 \mathrm{ft})$ and to the quartz-latite lava at Bullfrog Mountain and at Tram Ridge (figs. 1 and 10). In drill hole USW-G2, the Lithic Ridge Tuff is underlain by altered quartz-latitic lava. At the type locality at Lithic Ridge (fig. 4), the unit is intruded by dacite plugs and dikes somewhat similar petrographically to the dacite flow breccias that overlie the unit in drill holes USW-G1, - H1, and -G2. In holes UE25b-1 and J-13, a thin, bedded-tuff interval separates the Lithic Ridge Tuff from the overlying Tram Member of the Crater Flat. In exposures south of Skull Mountain a thin ash-flow tuff, probably the Lithic Ridge, is intercalated in tuffaceous sedimentary rocks of Pavits Spring (Poole, Elston, and Carr, 1965) about $90 \mathrm{~m}(300 \mathrm{ft}$ ) below the base of the Bullfrog Member.

The Lithic Ridge Tuff at the type locality has about 3 percent phenocrysts and a few percent lithic fragments in the lower part, and about 9 percent phenocrysts and 10 percent lithic fragments in the upper part. The groundmass is white and zeolitic, and, in drill cores from holes in Yucca Mountain, most of the tuff is slightly to partially welded, zeolitized, and argillized. Near the top, the tuff is moderately welded at Yucca Mountain and contains 18 percent phenocrysts (fig. 8). At the Pahute Mesa locality the Lithic Ridge is partly vitric and contains well-preserved hornblende and clinopyroxene. The lithic-fragment content generally ranges from about 5 to 25 percent, and no occurrences are known in which the lithic content is less than 3 percent.

The persistence of the lithic-fragment content and the phenocryst assemblage make the Lithic Ridge Tuff an excellent marker unit, readily identifiable from a single thin section. The lithic-fragment assemblage is marked by predominant pilotaxitic lava and subordinate spherulitic rhyolite. The rhyolite contains brown crystallite filaments that resemble hair under a magnification of $100 \times$. The felsic phenocryst ranges are unusual and are similar to those of the underlying, cogenetic rhyolite lava (fig. 6), and, moreover, at least five microphenocrysts of sphene, or its alteration products, occur in every thin section. Rare hornblende occurs only as microphenocrysts, in contrast to the greater abundance and larger size of hornblende crystals in the tuff of Yucca Flat and the Bullfrog Member of the Crater Flat Tuff. Although the quartz content of the Lithic Ridge overlaps slightly with that of members of the Crater Flat Tuff, nearly all lithic-rich samples from the Tram Member lack spherulitic lithics and have more quartz. Quartz phenocrysts of the Bullfrog and Prow Pass
Members are not only more abundant than those in the Lithic Ridge, but are highly resorbed as well.

As shown by exposures at Tippipah Point (fig. 5), the Lithic Ridge Tuff is loosely bracketed between the Redrock Valley Tuff, dated at 15.7 m.y., and the Grouse Canyon Member, dated at 13.7 m.y. In Beatty Wash, the Lithic Ridge rests on lavas dated at 13.9 m.y., so the age of the Lithic Ridge is about $13.8 \mathrm{~m} . \mathrm{y}$.

\section{DACITE INTRUSIVE AND FLOW BRECGIA}

Dacite (Spengler and others, 1981, p. 36 and fig. 4) flow breccia was penetrated between the Tram Member of the Crater Flat Tuff and the underlying Lithic Ridge Tuff in holes USW-G1, -G2, - H1, - H5, and - H6, but is absent in holes USW-G3, UE25b-1H, and J-13 (fig. 7). The dacite is thickest, about $250 \mathrm{~m}(800 \mathrm{ft})$, in drill hole USW-H6 (fig. 9). In holes USW-G1 and -H1 the dacite flow breccia is about $120 \mathrm{~m}(400 \mathrm{ft})$ thick, whereas in USW-G2 it is much thinner-about $35 \mathrm{~m}$ (115 ft) thick. Lava is present in the interior of the flow breccia. Thus, the unit thickens to the northwest beneath Yucca Mountain and pinches out southeastward.

The dacite intrusive plug that cuts the Lithic Ridge Tuff (fig. 4) at Lithic Ridge is apparently truncated by the present erosional surface, which may in part include an exhumed surface older than the tuffs of Calico Hills. The dacite intrusive rocks do not cut units younger than the Lithic Ridge Tuff.

The petrography of the dacite flow breccia penetrated in hole USW-G1 is shown graphically on figure 8. Phenocrysts constitute about 13 percent of the rock, and 70 to 80 percent of the phenocrysts are plagioclase. The remaining phenocrysts are all mafic, consisting of about equal amounts of hornblende and clinopyroxene. Apatite microphenocrysts, typical of lavas of intermediate composition, are fairly common, and a few grains of zircon occur in one of the thin sections. The groundmass of the vitrophyre is perlitic, indicating an intermediate to rhyolitic composition. Norms calculated from chemical analyses of two samples of the flow breccia in USW-G1 show 20 percent normative quartz (Spengler and others, 1981), indicating the rock is dacite rather than andesite (O'Connor, 1965).

The dacite intrusive at Lithic Ridge was originally mapped as andesite (Orkild and O'Connor, 1970), but it is even more silicic than the flow breccia in the drill holes and may actually be a rhyodacite. (See fig. 6.) One thin section of the unit showed that phenocrysts constitute only 8 percent and that about 60 percent of the phenocrysts are plagioclase and the remaining 40 percent are mafic minerals. However, the mafic miner- 
als include about equal amounts of biotite and hornblende and have subordinate orthopyroxene and clinopyroxene, suggesting a slightly more silicic composition than that of the flow breccia penetrated in USWG1. Microphenocrysts of apatite are present but zircon is rare. The phenocryst composition of the dacite plug at Lithic Ridge is generally like that of some lavas of the younger Wahmonie and Salyer Formations, but all lavas of the Wahmonie are phenocryst-rich (Poole, Carr, and Elston, 1965, p. A41-A43).

\section{CRATER FLAT TUFF AND RELATED LAVA}

The Crater Flat Tuff was named by Byers and others (1976b) from exposures around Crater Flat. The best exposure, near U.S. Highway 95 (fig. 9), includes the Bullfrog and Prow Pass Members separated by a monolithologic breccia of Bullfrog clasts in a matrix of nonwelded Bullfrog tuff. The underlying Tram Member, defined in this report, is not present at this locality. A tuff that is exposed mainly in fault blocks between the north end of Crater Flat and Beatty Wash was formerly correlated with the Bullfrog (Byers and others, $1976 \mathrm{~b}$ ) but is now recognized as the Tram. Locally a lava flow, similar in phenocryst mineralogy to the Bullfrog, occurs between the Bullfrog and the Tram in the area between Beatty Wash and Crater Flat (fig. 9; Byers and others, 1976b, fig. 4, p. 14).

The three ash-flow units of the Crater Flat Tuff are present in drill holes on Yucca Mountain, in well J-13, and at Mara Wash (fig. 11; Poole, Elston, and Carr, 1965). Although the presence of three ash-flow tuffs at Mara Wash had been known for some time, Byers and others $(1976 \mathrm{~b}$, p. 10) regarded the middle tuff, now known to be Bullfrog, as a local cooling unit. The lowermost tuff unit at Mara Wash probably correlates with the Tram.

\section{TRAM MEMBER}

TYPE LOCALITY

The Tram Member, the oldest ash-flow tuff of the Crater Flat Tuff, is here named from exposures on the north slope of Tram Ridge ${ }^{3}$ (figs. 1, 12 and 13). The type locality is designated as along Beatty Wash northeastward from the outcrops where the Tram Member rests unconformably on the Lithic Ridge Tuff and on the rhyolite and quartz latite lavas under the Lithic Ridge (figs. 12 and 13). The top of the Tram is eroded in the upthrown fault block northwest of the large, pos-

\footnotetext{
3"Tram Ridge" is a newly established geographic name that is not shown on older topographic maps of the area.
}

sible caldera fault under Tram Ridge (fig. 13). On the southeast side of this fault block, the Tram is overlapped by the Paintbrush and Timber Mountain Tuffs (fig. 12). The large northeasterly trending possible caldera ring fracture fault under Tram Ridge displaces the Paintbrush but not the Timber Mountain Tuff.

The total thickness of the Tram Member is not known at the type locality because of erosion on the upthrown block and concealment by the Bullfrog Member and younger rocks on the downthrown block, but the minimum thickness is estimated with the aid of the cross section shown on figure 13. The strike and dip shown on figure 12, however, are not representative of the entire exposure of the Tram along Beatty Wash. The minimum thickness exposed is estimated to be at least about $180 \mathrm{~m}(600 \mathrm{ft})$ including approximately 60 $m(200 \mathrm{ft})$ of shard-rich nonwelded to partially welded tuff in the lower part. The thickness of the Tram in the downfaulted possible caldera block may be much greater.

\section{DRILL HOLE USW-GI}

Drill hole USW-G1 at Yucca Mountain (fig. 9; Spengler and others, 1981) penetrated the Tram Member from 804.5 to $1,073.5 \mathrm{~m}(2,639.4-3,522.0 \mathrm{ft})$, a total thickness of $269.0 \mathrm{~m}(882.6 \mathrm{ft})$. The Tram in hole USWG1 is overlain by a thin sequence of bedded tuff beneath the Bullfrog Member and underlain by bedded tuff overlying the dacite flow breccia of USW-G1. The lower half of the Tram in hole USW-G1 is nonwelded to partially welded, and rhyolite, quartz latite, and dacite lava xenoliths constitute as much as 50 percent of the rock. These xenoliths contain sparsely disseminated pyrite, and the tuff matrix is locally zeolitic and argillic. The upper half of the unit is partially to moderately welded and devitrified and has only $3-5$ percent lava xenoliths. For a complete description of the Tram Member penetrated in hole USW-G1, see Spengler and others $(1981$, p. 17-18).

\section{DISTRIBUTION AND THICKNESS}

The Tram Member is distributed in an east-west pattern from Mara Wash near Frenchman Flat to Daylight Pass on the Nevada-California State line, where there are at least two complete exposures of nonwelded to partially welded Tram, $50 \mathrm{~m}(164 \mathrm{ft})$ or less in thickness. Only the upper few meters of the nonwelded ashflow tuff are exposed at Mara Wash (fig. 11). The member was penetrated in all the deep drill holes in the Yucca Mountain area, including well J-13. In most of the outcrop exposures, the base of the unit is either covered or cut out by faulting, except at the type locality near Tram Ridge, where the top has been eroded. 


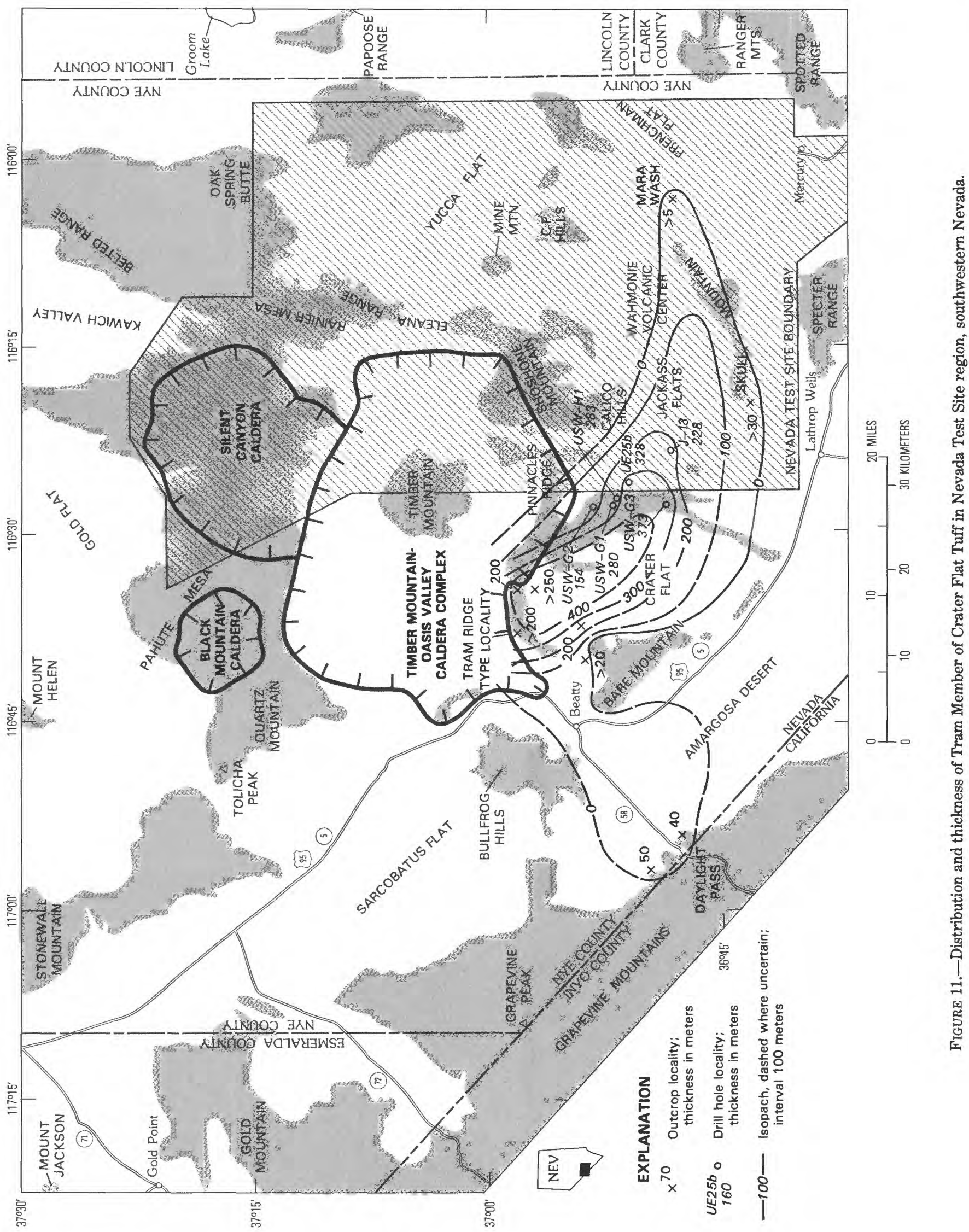




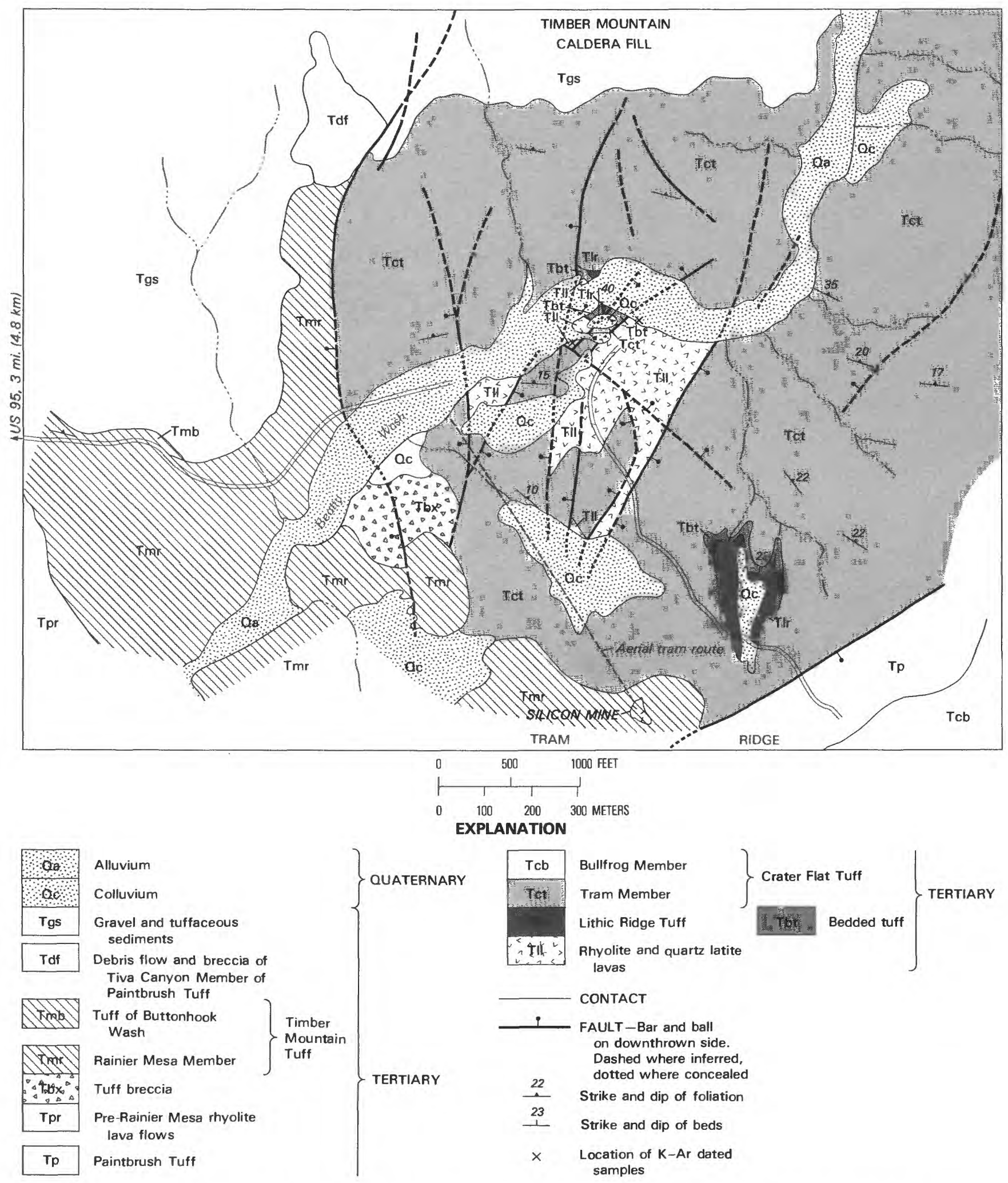

Figure 12.-Geologic relations of Tram Member of Crater Flat Tuff in the Tram Ridge-Beatty Wash area, southwestern Nevada. 


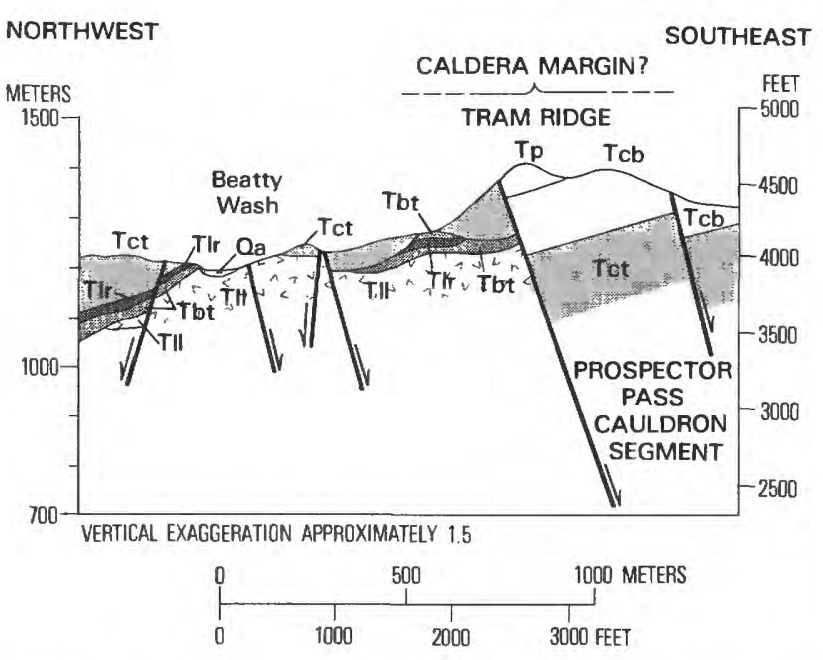

FIGURE 13.-Geologic section from northwest to southeast through Tram Ridge, showing relations of Tram Member to lava flows and possible cauldron structure. See figure 12 for explanation of symbols.

The Tram is apparently thickest in the northern Crater Flat area, where it has the crystalline texture characteristic of thick intracaldera sequences. However, the greatest minimum thickness actually exposed there is only about $250 \mathrm{~m}(825 \mathrm{ft})$.

In general, the bedded tuff interval between the Tram and the Bullfrog is several meters thicker than the bedded tuffs between the Bullfrog and Prow Pass Members.

\section{LITHOLOGY AND PETROGRAPHY}

The Tram Member, as penetrated in most of the drill holes at Yucca Mountain, can be subdivided into a lower lithic part, containing abundant primarily rhyolitic and intermediate composition lava xenoliths, and an upper part much poorer in lithic fragments. The Tram Member generally contains more xenoliths than the overlying Bullfrog, but this criterion is not everywhere reliable, and recourse must often be made to petrography to differentiate the two. Lithic parts of the Tram are similar megascopically to the underlying Lithic Ridge Tuff, but contain much more quartz and only very rare sphene. At the type locality at Tram Ridge, near northern Crater Flat, and near the distal edges of the member (fig. 11), lithic fragments are much less common than in drill cores from under Yucca Mountain, and for this reason the unit is difficult to distinguish from the Bullfrog in outcrop or hand specimens.

Near northern Crater Flat and south of Skull Mountain, the bedded tuffaceous interval between the Tram and the Bullfrog contains a distinctive bed, about a meter thick, of colorful to white opalized or jasperized tuffaceous siltstone that is a useful stratigraphic marker.

Identification of the Tram can be confirmed by thinsection modal analysis. In drill hole USW-G1, the Tram has considerably more quartz phenocrysts (fig. 8) than the Bullfrog, and they are only slightly resorbed, in contrast to the strongly resorbed phenocrysts in the Bullfrog. As shown on figure 6, however, a comparison of the quartz phenocryst content indicates considerable overlap between ranges of outcrop samples of the Tram and the Bullfrog. The plagioclase-alkali feldspar ratio is generally a little higher in the Bullfrog than in the Tram, and hornblende is more abundant.

The Tram also has considerably fewer spherulitic rhyolite xenoliths than the underlying Lithic Ridge Tuff. In drill hole USW-G1, unit A of the older ashflow tuffs is very similar to the Tram. Unit A differs from the Tram only in containing few or no rhyolite or intermediate lava xenoliths, and in containing many spherulitic rhyolite fragments that have hairlike crystallites similar to those seen in the Lithic Ridge Tuff and the tuff of Yucca Flat.

As discussed later, the Tram is also distinct from other Crater Flat Tuff units in having reversed remanent magnetism.

\section{AGE AND RELATION TO OTHER UNITS}

No potassium-argon age determinations have been made on the Tram, mainly because of hydrothermal alteration, but its age is well established from relations to other units. However, relations to the Grouse Canyon Member of the Belted Range Tuff, which is a widespread stratigraphic marker in the northern part of the NTS, dated at about 13.7 m.y. (see footnote 1, above), are not precisely known, except that the two units are approximately the same age. The Lithic Ridge Tuff at Tippipah Point (fig. 5) is beneath the Grouse Canyon horizon as mapped by Orkild (1963). A boulder bed that occurs beneath the Bullfrog Member at the Crater Flat Tuff type locality near U.S. Highway 95 (fig. 9) contains welded Grouse Canyon and Tram clasts. Another occurrence of smaller and much less abundant boulders of Belted Range Tuff affinities occurs stratigraphically between the Tram and Bullfrog Members in the Daylight Pass area near the California-Nevada State line (fig. 11). Lava just beneath the Tram and the Lithic Ridge in Beatty Wash has been dated at 13.9 m.y. (R. F. Marvin, written commun., 1980). It appears that the 
Tram and the Grouse Canyon are nearly the same age-about 13.7 m.y. Discussion presented in the concluding section suggests that the Tram may be the younger of the two.

\section{BULLFROG MEMBER AND PETROGRAPHICALLY SIMILAR LAVA}

The Bullfrog Member was originally named and defined as the lower of two members of the Crater Flat Tuff (Byers and others, 1976b, p. 11-14), but we now know it as the middle member and designate the petrographically similar Tram as the lower member. The distribution of the Bullfrog is similar to that of the Tram Member (figs. 11 and 14), except that the Bullfrog occurs over a larger area. Near its western known limits the Bullfrog is somewhat thicker and more densely welded than the Tram. At its eastern limits near Scarp Canyon, the Bullfrog is nonwelded to partially welded, and at Nye Canyon only $10 \mathrm{~m}$ (35 $\mathrm{ft}$ ) of related ash-fall tuff is present.

The Bullfrog Member under Yucca Mountain consists of nonwelded to partially welded, zeolitic upper and lower parts and a central zone, 30-90 m (100-300 ft) thick, of moderately to densely welded tuff. At Prow Pass, only the upper $70 \mathrm{~m}$ (230 ft) of welded Bullfrog is exposed, and it contains an assortment of xenoliths, including plagioclase porphyritic rhyodacite(?) and granitic rock not seen elsewhere. At one locality at Prow Pass, a train of xenoliths the size of small boulders occurs along a parting about $10 \mathrm{~m}(35 \mathrm{ft})$ below the top of the Bullfrog. Locally, in a few zones observed in the drill holes, the Bullfrog contains rare mudstone xenoliths, but these are more typical of the overlying Prow Pass. At the type locality of the Crater Flat (fig. 14), the Bullfrog is partly vitric and nonwelded to densely welded. It is overlain by a breccia of welded, devitrified Bullfrog clasts in a nonwelded, glassy, Bullfrog-like matrix.

Petrographically, the Bullfrog Member generally contains about twice as much plagioclase as alkali feldspar, and about 10 to 25 percent of the phenocrysts are quartz (fig. 6). Most of the quartz, however, is moderately to strongly resorbed. The mafic minerals are principally biotite and subordinate hornblende, but hornblende or its pseudomorphs occur in almost every thin section examined. The overlying Prow Pass Member also contains sparse hornblende, but its general lack of biotite and its content of orthopyroxene make it distinctive (fig. 6). Inasmuch as the Prow Pass also has resorbed quartz, distinguishing the two units where the mafic phenocrysts are altered can be difficult.

Rhyolite lava that occurs between the Tram and the Bullfrog east of Tram Ridge (fig. 14; Byers and others,
$1976 \mathrm{~b}$, p. 9) is petrographically similar to the Bullfrog. As seen on figure 6 , the lava petrographically resembles both the Bullfrog and the Tram in phenocryst mineralogy, but its hornblende content is more like that of the Bullfrog.

Two potassium-argon dates were obtained (Marvin and others, 1970) from the Bullfrog Member, namely 14.0 m.y. on biotite and 13.0 m.y. on sanidine (Marvin and others, 1970; Byers and others, 1976b). Previously, we had accepted the older age of $14.0 \mathrm{~m} . \mathrm{y}$. because the Bullfrog was thought to underlie the Grouse Canyon Member, then dated at $13.8 \mathrm{~m} . \mathrm{y}$. (Marvin and others, 1970). With the present knowledge, it seems best to average the two ages at $13.5 \mathrm{~m} . \mathrm{y}$.

\section{PROW PASS MEMBER}

The Prow Pass Member of the Crater Flat Tuff was defined by Byers and others (1976b, p. 14-15) as the upper of two ash-flow tuffs that crop out at Prow Pass (fig. 15) beneath the tuffs and rhyolite lavas of Calico Hills. Elsewhere, in the drill holes at Yucca Mountain, and at the type locality of the Crater Flat Tuff, the Prow Pass invariably rests on several meters of bedded tuff above the Bullfrog Member; no rhyolite lava has yet been found between the two members. The distribution and thickness of the Prow Pass is shown on figure 15. The Prow Pass is thinner than the Bullfrog almost everywhere the two members are exposed (figs. 14 and 15).

Inasmuch as the Prow Pass Member overlies the Bullfrog, it must also be stratigraphically higher than the Grouse Canyon Member and the tuffs of Sleeping Butte (fig. 2). The Prow Pass and the Bullfrog underlie the Wahmonie and Salyer Formations (Poole, Carr, and Elston, 1965) at Mara Wash and also underlie the tuffs of Calico Hills at Prow Pass and in the drill holes on Yucca Mountain.

Lithologically, the Prow Pass and the Bullfrog are similar and would be difficult to distinguish were it not for the fact that the two units occur in sequence in most areas. At its type locality, the Prow Pass is exposed along a north-south strike length of about $1 \mathrm{~km}$ (0.6 mile), and from north to south the unit thickens from about $45 \mathrm{~m}(150 \mathrm{ft})$ to $75 \mathrm{~m}(250 \mathrm{ft})$ and becomes more densely welded. Near its southernmost exposure at Prow Pass, the member is $77 \mathrm{~m}$ (252 ft) thick and is underlain by $16 \mathrm{~m}(52 \mathrm{ft})$ of thick-bedded ash-fall tuff.

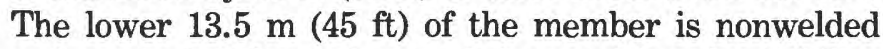
and separated from the overlying part by about $0.3 \mathrm{~m}$ $(1 \mathrm{ft})$ of thin-bedded ash-fall tuff. The lower part of the Prow Pass contains sparse reddish-brown mudstone fragments, similar to those seen in the lower part of the thicker Prow Pass in the Yucca Mountain drill 
CRATER FLAT TUFF AND RELATED LAVA

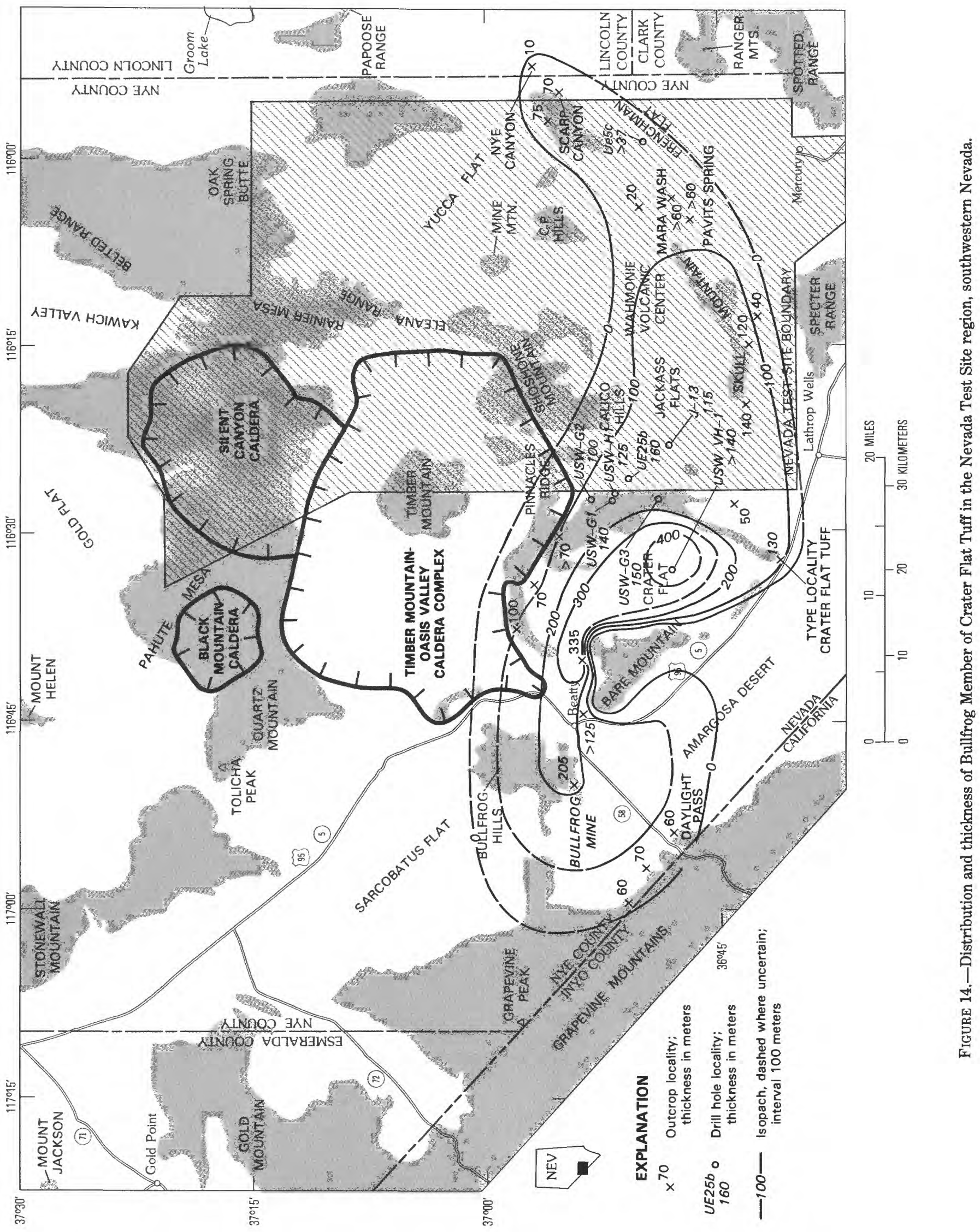




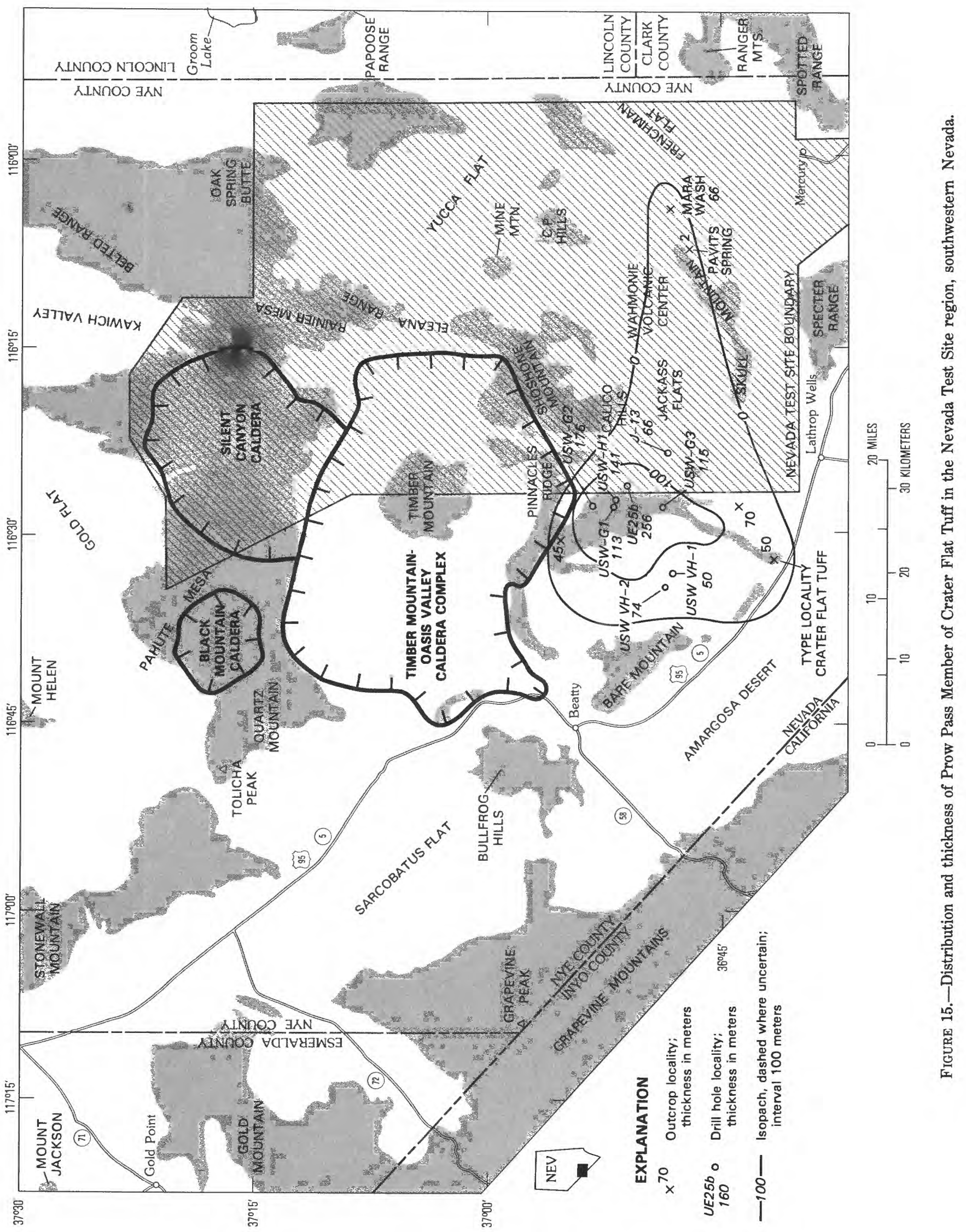


cores, but no bedded interval separates the two parts in the drill holes. At Prow Pass, rare granitic xenoliths were observed in the upper part, which is locally welded and contains a basal vitrophyre $0.1 \mathrm{~m}$ thick.

The generalized phenocryst mineralogy of 14 outcrop samples of the Prow Pass is shown on figure 6. Both the Prow Pass and the Bullfrog contain 10 to 20 percent phenocrysts, and both contain highly resorbed ("wormy") quartz phenocrysts. The feldspar ratio in the Prow Pass is generally subequal, in contrast to plagioclase dominance in the Bullfrog, but there is some overlap. The main features that distinguish the Prow Pass from the Bullfrog are its content of mudstone fragments, as mentioned above, the presence of orthopyroxene phenocrysts, and the scarcity of biotite and hornblende. Rare pilotaxitic lava xenoliths are also found in the Prow Pass.

The age of the Prow Pass is bracketed by average potassium-argon ages of $13.5 \mathrm{~m} . \mathrm{y}$. for the underlying Bullfrog and 13.4 m.y. for the overlying tuffs of Calico Hills (Marvin and others, 1970).

\section{MAGNETIC PROPERTIES OF CRATER FLAT TUFF AND SUBJAGENT UNITS}

Magnetic characteristics of welded tuffs and lava flows can be useful in correlation of units, especially where oriented drill core is available. Such data are also necessary for interpretations of aeromagnetic maps over complex volcanic rock terrain. Table 1 gives preliminary data (courtesy of J. G. Rosenbaum, U.S. Geological Survey) for some of the major prePaintbrush Tuff units in the southwestern NTS area. The samples are demagnetized drill core and oriented outcrop samples.

The tuff of Yucca Flat has been determined to be magnetically reversed (table 1). Drill cores from Yucca Flat support this determination, but few measurements of declination are presently available.

Remanent magnetism of the Lithic Ridge Tuff measured to date is variable; the remanence is apparently weak and has a low inclination and an intermediate direction. Lava flows underlying the Lithic Ridge and the Tram, however, seem to have a consistently reversed direction, based on field measurements made with a portable fluxgate magnetometer and on a few oriented samples drilled and measured in the laboratory. The dikes on Bare Mountain are also reversed.

The Tram Member has a relatively consistent reversed magnetization (table 1 ), even in outcrops that are not densely welded, and is therefore easily distinguished from the Bullfrog and Prow Pass Members, both of which have normal remanence.

\section{GALDERAS RELATED TO GRATER FLAT TUFF AND SUBJAGENT UNITS}

The principal purpose of this report is to revise the stratigraphy of the Crater Flat Tuff, but new data and geologic relationships also provide a perspective on source areas and structural setting of the prePaintbrush Tuff volcanic units in the southwestern NTS area. Therefore, a brief discussion follows of the volcano-tectonic history as it is presently understood.

The probable source area of the Crater Flat Tuff, a large structural depression best expressed topographically in southern Crater Flat, is here named the Crater Flat-Prospector Pass caldera complex (fig. 1). The northern part of this feature, believed to be the source of the Tram Member, is named the Prospector Pass $^{4}$ caldera segment; the name is taken from a pass between Beatty Wash and northern Crater Flat in northwesternmost Yucca Mountain. (See Byers and others, 1976b, fig. 4.) The northeastern part of the Prospector Pass segment is truncated by the younger Timber Mountain-Oasis Valley caldera complex.

Three main lines of evidence are sigmificant in identifying structures associated with eruption of these tuffs: (1) geophysical data, (2) distribution and thickness of the ash-flow tuffs and their associated lava flows, and (3) key geologic relations in the postulated caldera area.

\section{GEOPHYSICAL EVIDENCE}

Many new geophysical data are available from recent investigations of the region surrounding Yucca Mountain. The most significant for volcano-tectonic interpretation include gravity, magnetic, and seismic surveys.

Detailed gravity data show that Crater Flat itself is a large compound gravity low (Snyder and Carr, 1982), which is a southward extension of a regional low associated with several caldera complexes, including Silent Canyon (Orkild and others, 1968) and Timber Mountain (fig. 16). Although calderas do not invariably produce distinct gravity lows, most calderas in southern Nevada are areas of relatively low density crustal rocks, including thick accumulations of tuff and alluvium. The absence of coherent Paleozoic and Proterozoic sedimentary rocks beneath the calderas can also contribute to a negative gravity signature.

The gravity low at Crater Flat is elongate northsouth but is separated into north and south areas by a septum across central Crater Flat (Snyder and Carr,

"Prospector Pass" is a newly established geographic name that is not shown on older topographic maps of the area. 


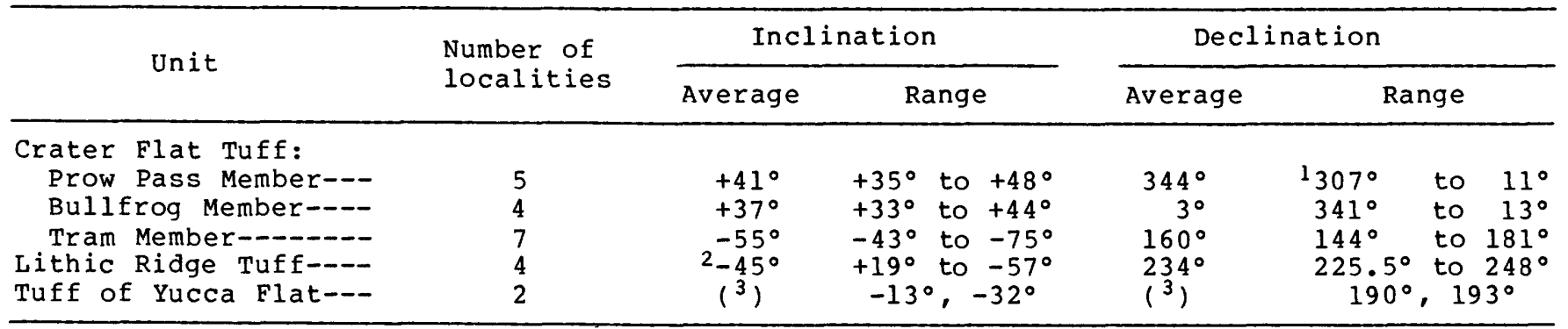

1 Some of the variation may be due to rotation of oriented core.

2 If one probably anomalous inclination is discarded, the average inclination is $+4^{\circ}$. 3 Because only two samples were obtained from outcrop, averages would have little validity. Average inclinations in core from drill holes U3j9 and UE7ba in Yucca Flat are $-27^{\circ}$ and $-45^{\circ}$, respectively. Average declinations could not be determined from core.

1982). The general configuration of the low is like that of a sector graben-a collapse segment on the flanks of a volcanic edifice. However, the section penetrated by drill hole USW-VH1 (Carr, 1982) in south-central Crater Flat showed that it is unlikely the hole is in a sector graben related to the Timber Mountain-Oasis Valley caldera complex; no unusual thickening of the Paintbrush Tuff occurs, and it is not downfaulted to great depths, at least not at USW-VH1. Gravity data (Snyder and Carr, 1982) suggest there are more than $3,000 \mathrm{~m}(10,000 \mathrm{ft})$ of volcanic and Tertiary sedimentary rocks in the Crater Flat depression. As drill hole USW-VH1 showed, the Paintbrush Tuff has a normal thickness and lithology for the area, and the base is

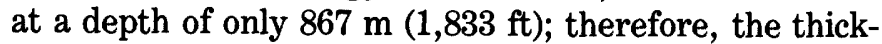
ening of the volcanic rocks must occur in the older units.

Detailed, draped aeromagnetic surveys of the Crater Flat area (U.S. Geological Survey, 1978, 1979), provided one of the first clues that some previous correlations of Crater Flat Tuff units were incorrect. Study of the aeromagnetic map also revealed several significant anomalies (fig. 17), one of which was drilled to $762 \mathrm{~m}(2,500 \mathrm{ft})$ at USW-VH1. This circular positive magnetic anomaly in southern Crater Flat, about $7 \mathrm{~km}$ $(4.3 \mathrm{mi})$ across, is thought to represent a resurgent dome that formed in the caldera after eruption of the Bullfrog Member (Carr, 1982, p. 8-9).

Aeromagnetic evidence for a possible caldera related to the Tram Member in northern Crater Flat is not definitive, but a general magnetic low is present in the area, accentuated by strongly negative anomalies wherever the Tram Member is exposed (U.S. Geological Survey, 1978). Because of highly complex structure and hydrothermal alteration, especially in the northern part of the Prospector Pass segment, aeromagnetic and other geophysical evidence of caldera structure is tenuous.

Several kinds of seismic evidence support the concept of a Crater Flat caldera complex. Multiple recordings of seismic waves from nuclear explosions under Pahute Mesa show traveltime delays of nearly 0.5 seconds across Crater Flat, compared to the region south of Crater Flat (W. D. Mooney and Lynn Hoffman, U.S. Geological Survey, written commun., 1981). An unreversed seismic line recorded a shot from near Beatty west-east across Crater Flat and Yucca Mountain (W. D. Mooney, written commun., 1982); this method also detected significant traveltime delays in Crater Flat. The presence of lower velocity rocks in Crater Flat supports the interpretation that a deep, tuff-filled depression exists in that area.

\section{DISTRIBUTION AND THICKNESS OF THE TUFFS}

Isopach information presented earlier (figs. 11, 14, and 15) clearly shows the geographic relation between the probable source area in Crater Flat and the thickness and distribution of the three members of the Crater Flat Tuff. The east-west elongation of distribution 


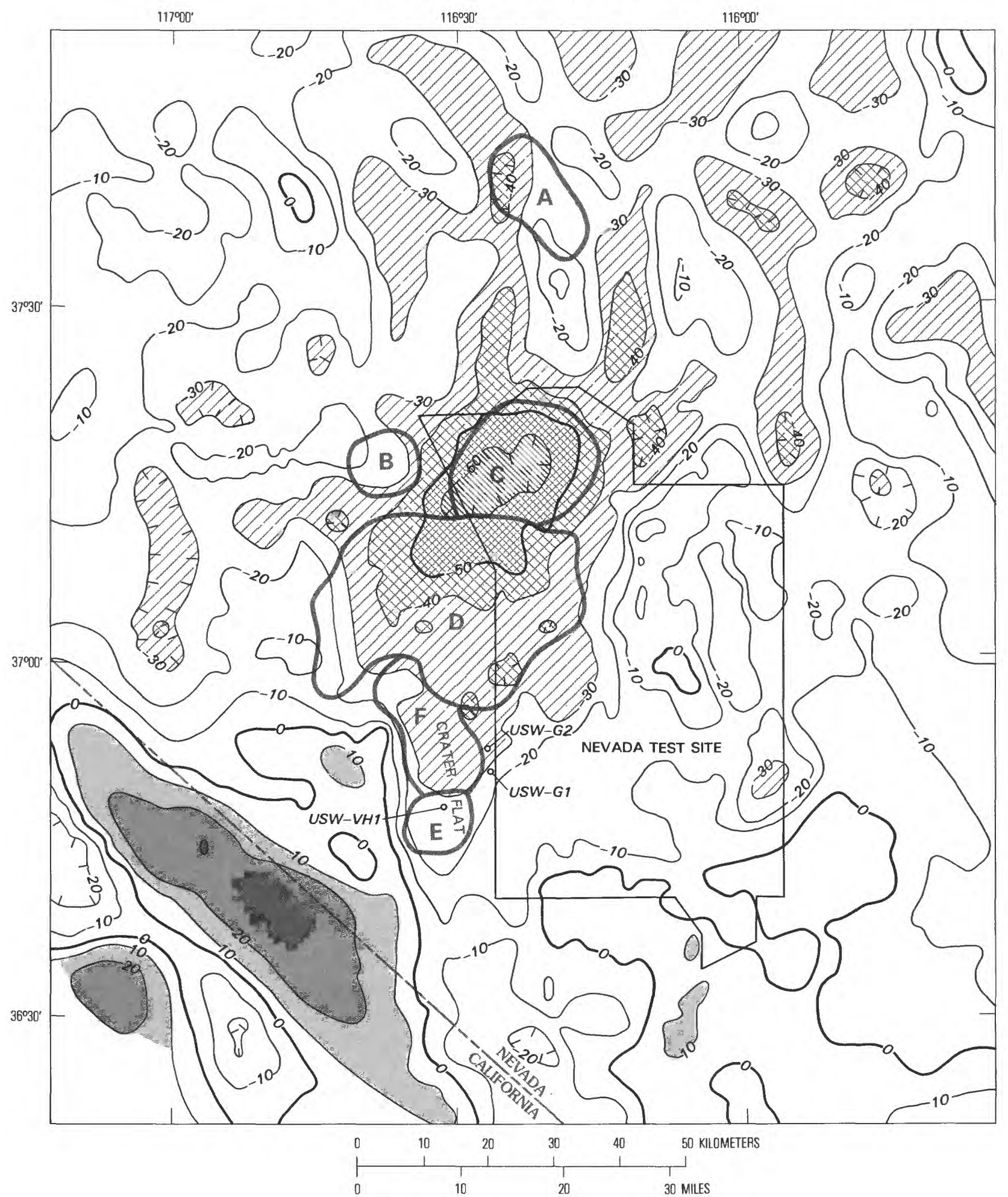

FIGURE 16.-Generalized Bouguer gravity map of the NTS region, showing the regional gravity low associated with several caldera complexes. Contour interval $10 \mathrm{mGal}$. A, Cathedral Ridge caldera; B, Black Mountain caldera; C, Silent Canyon caldera; D, Timber Mountain-Oasis Valley caldera complex; E and F, Crater Flat-Prospector Pass caldera complex. Locations of drill holes USW-VH1, -G1, and-G2 also shown. Based on gravity studies by R. W. Saltus (written commun., 1982). 


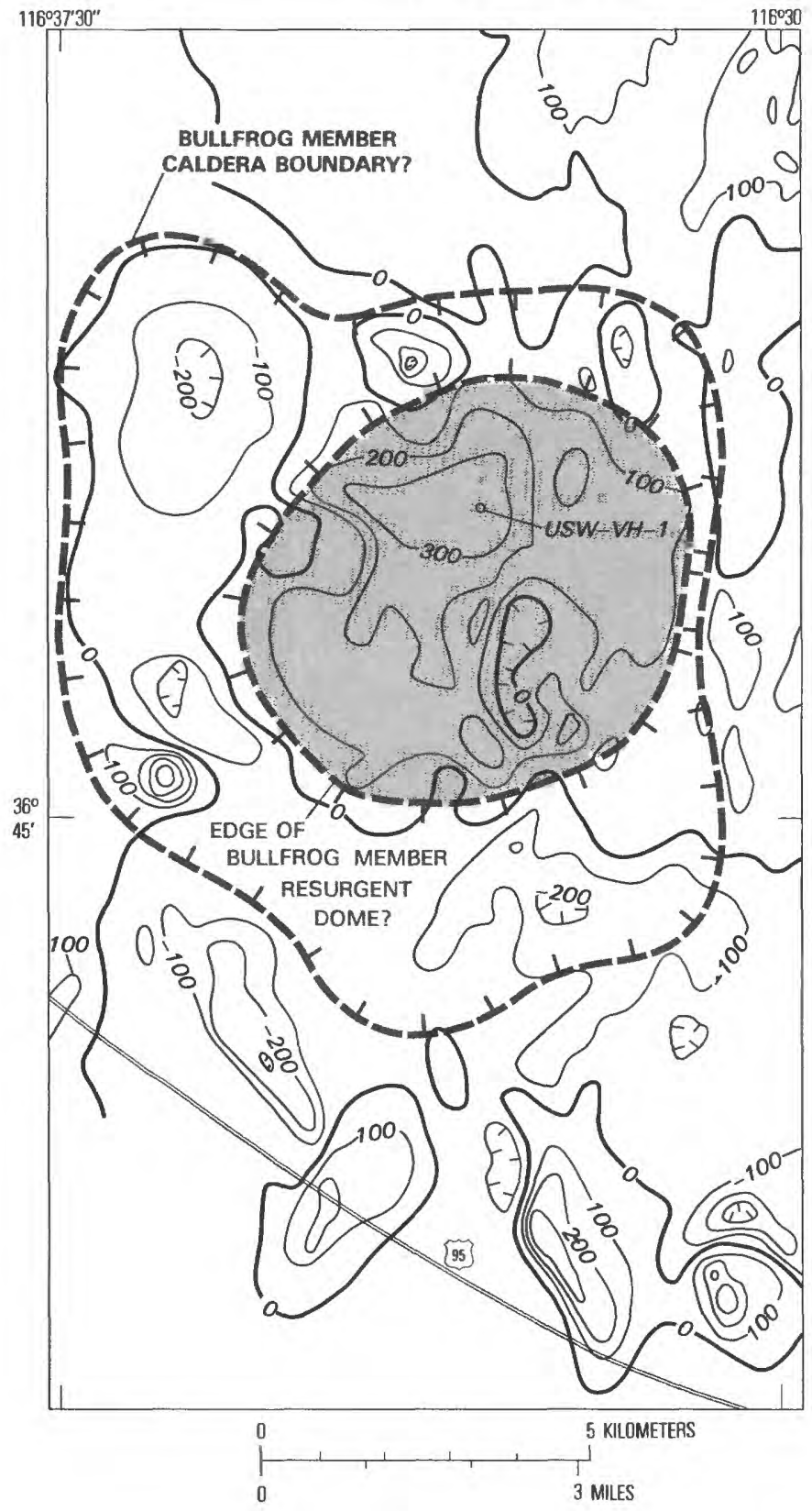

Figure 17.-Aeromagnetic map of southern Crater Flat area, showing caldera boundary and the proposed resurgent dome of the Bullfrog caldera. Contour interval 100 gammas. From U.S. Geological Survey $(1978,1979)$.

of the Crater Flat is similar to that of the Paintbrush Tuff (Byers and others, 1976b), but, significantly, none of the members of the Crater Flat are found north of latitude $37^{\circ} \mathrm{N}$. Lobes of these tuffs could be concealed beneath the Timber Mountain-Oasis Valley caldera complex, however. Owing to extensive cover by younger units, data on the thickness of the Crater Flat are spotty, and many thicknesses shown on the isopach maps (figs. 11, 14, and 15) are minima. There is enough control, however, to show that the thickest part of the Tram is in the northern Crater Flat area, and the thickest part of the Bullfrog is in the general area from north of Bare Mountain to Crater Flat. Drill hole USW-VH1 in south-central Crater Flat bottomed in the Bullfrog Member after 141 meters (463 ft) were penetrated (Carr, 1982). Textures and welding of the Bullfrog in continuous core from this hole strongly suggest much more of the member lies beneath the section penetrated. As mentioned previously, aeromagnetic data support this conclusion.

The Prow Pass Member appears to be thickest in the Yucca Mountain area (fig. 15), but the relatively thin sequence penetrated within the postulated caldera at drill hole USW-VH1 seems to argue against the caldera concept. However, the postulated resurgent dome in the Bullfrog caldera in the USW-VH1 area could cause the observed thinning of the Prow Pass. The exact location of a collapse related to the Prow Pass remains a question; the total volume of the Prow Pass is not great, so a large or deep collapse area is not required.

\section{GEOLOGIC RELATIONS}

Geologic relations that help associate caldera locations and structures with individual members of the Crater Flat Tuff are both subtle and discontinuous because exposures of the members are few. One of the most useful clues is the distribution of lava flows erupted during the magmatic episodes that generated the tuffs. As described previously, several dacitic to rhyolitic lavas and intrusive bodies are exposed in the southwestern NTS area and penetrated by several drill holes at Yucca Mountain (fig. 9). These rocks all predate the Bullfrog Member, and many are beneath the Lithic Ridge Tuff. Scattered exposures of lavas and dikes flank Crater Flat (fig. 9), except on the southeast side, where the only pre-Bullfrog rocks exposed are those at the type locality of the Crater Flat Tuff. Dikes on Bare Mountain show a slightly arcuate pattern, concave toward the postulated caldera complex, suggestive of outer ring-fracture intrusions. As mentioned earlier, these dikes are petrographically similar to the other rhyodacitic bodies, and one has been dated at 13.9 m.y., identical in age to the lavas beneath the Lithic Ridge Tuff at Beatty Wash. In addition, some of the dikes on Bare Mountain are composite, consisting of a quartz latitic or rhyodacitic border phase and a central, quartz-rich, rhyolitic phase, the same sequence observed in the lavas in Beatty Wash.

The abundance of lithic fragments, including many lava clasts, in the Tram and the Lithic Ridge, especially 
in the drill holes at Yucca Mountain, shows that these tuffs were erupted through a terrain containing thick lava flows. As flows are not present southeast of hole USW-G1, we infer that the sources of the Tram and Lithic Ridge Members lie to the west or northwest, perhaps in the general area between Crater Flat and Beatty Wash.

At the type locality of the Crater Flat Tuff (fig. 14), a monolithologic breccia deposit of welded, devitrified Bullfrog Member occurs at the top of the Bullfrog. The lithology of the breccia fragments in that deposit is unlike that of any other local Bullfrog exposure. Small faults that cut the Bullfrog at this locality do not offset the overlying Prow Pass. These features suggest that abrupt tectonic movements accompanied the eruption of the Bullfrog Member and are a further indication that this locality is near the collapsed caldera associated with eruption of the Bullfrog. About $3 \mathrm{~km}(1.7 \mathrm{mi})$ to the north, at the southern extremity of the caldera complex, are several faults that trend northeast, parallel to the postulated caldera wall ( $F$ on fig. 18) and downthrown toward it.

Although, certainly, not all basalts in the Great Basin are associated with calderas, there is a strong tendency, especially for the more voluminous basalt flows, to occupy caldera ring fracture zones. The basalts of Crater Flat (Crowe and Carr, 1980) appear to be an example of flows that were localized by the deep-seated fracture system of the caldera but probably reached the surface along northeast-trending, riftlike fracture systems. Another basalt that may be a clue to caldera location is the group of 10-m.y.-old (R. F. Marvin, written commun., 1980) dikes on Yucca Mountain (fig. 18). One of these dikes occurs along a north-striking fault, but several others occur in fractures that form a northwesttrending zone. Taken together, the dikes suggest an arcuate pattern, slightly concave to the west-southwest, and we suggest that their location was controlled by a buried outer ring fracture related to the Prospector Pass segment of the caldera (fig. 18).

Scattered exposures of the Tram Member, between Beatty Wash and the north end of Crater Flat, are hydrothermally altered and broken by numerous small faults. The texture, welding, and crystallization of the Tram in these exposures are like those of very thick intracaldera ash-flow tuffs, such as the Ammonia Tanks Member of the Timber Mountain Tuff, as exposed on Timber Mountain (fig. 14), a resurgent dome in the center of the Timber Mountain caldera (Byers and others, 1976a, b). These characteristics, the fault pattern, and the relatively high structural position of the outcrops all suggest that this may be an eccentric resurgent area in the Prospector Pass segment of the caldera.

\section{RELATION BETWEEN TRAM AND GROUSE CANYON MEMBERS}

The discovery of welded tuff boulders of the Grouse Canyon and Tram Members beneath the Bullfrog Member established the stratigraphic relationship between the Bullfrog and the Grouse Canyon, but the exact Tram-Grouse Canyon volcano-tectonic and stratigraphic succession remains obscure. The following discussion, however, outlines present reasoning for tentatively concluding that the Tram is younger than the Grouse Canyon.

At the Crater Flat type locality near U.S. Highway 95 , the boulder bed beneath the Bullfrog contains very large clasts of Tram and Grouse Canyon material, some as much as $1.8 \mathrm{~m} \mathrm{(6} \mathrm{ft)} \mathrm{in} \mathrm{diameter;} \mathrm{virtually} \mathrm{no} \mathrm{other}$ units are represented in this deposit. In general, it resembles a flood-emplaced debris flow, and transport of such large boulders for any appreciable distance suggests a catastrophic flood or a relatively fluid volcanic mudflow, possibly caused by a sudden release of a large volume of water by dam breaching. The nearest Grouse Canyon welded tuff exposures are $65 \mathrm{~km}(40$ mi) north of the boulder bed exposure, but as outlined earlier, the Tram caldera is probably located in the northern part of Crater Flat. Its southern wall is postulated to be in north-central Crater Flat, about $15 \mathrm{~km}$ $(10 \mathrm{mi})$ north of the boulder bed outcrops. The Belted Range caldera, source of the Grouse Canyon, is about $80 \mathrm{~km}(50 \mathrm{mi})$ to the north, beneath Pahute Mesa. Had the Tram eruption and caldera collapse preceded the Grouse Canyon eruption, it seems unlikely that the Grouse Canyon boulders could have been transported across the Tram caldera in northern Crater Flat. Boulders of Grouse Canyon have also been noted at a locality about $3 \mathrm{~km}(1.8 \mathrm{mi})$ up Beatty Wash from the Tram type locality. The boulders occur as a thin lag deposit on top of the Tram Member and are preserved beneath the Rainier Mesa Member, now nearly stripped away at that location. It is reasonable to speculate that a lobe of the Grouse Canyon Tuff was present in the Beatty Wash-northern Crater Flat area, possibly as far south as the southern edge of the subsequent Tram caldera. We speculate that, after the Tram caldera collapsed, its south wall consisted largely of Tram Member on the rim, underlain by Grouse Canyon Member. A large lake could then have filled the Tram caldera and may have overflowed by breaching the south wall in a catastrophic flood or debris flow, which carried large boulders of Tram and some Grouse Canyon material southward about $15 \mathrm{~km}$ (10 mi) to their present location near U.S. Highway 95. Although highly speculative, this sequence of events seems a logical way to account for the known relationships. 


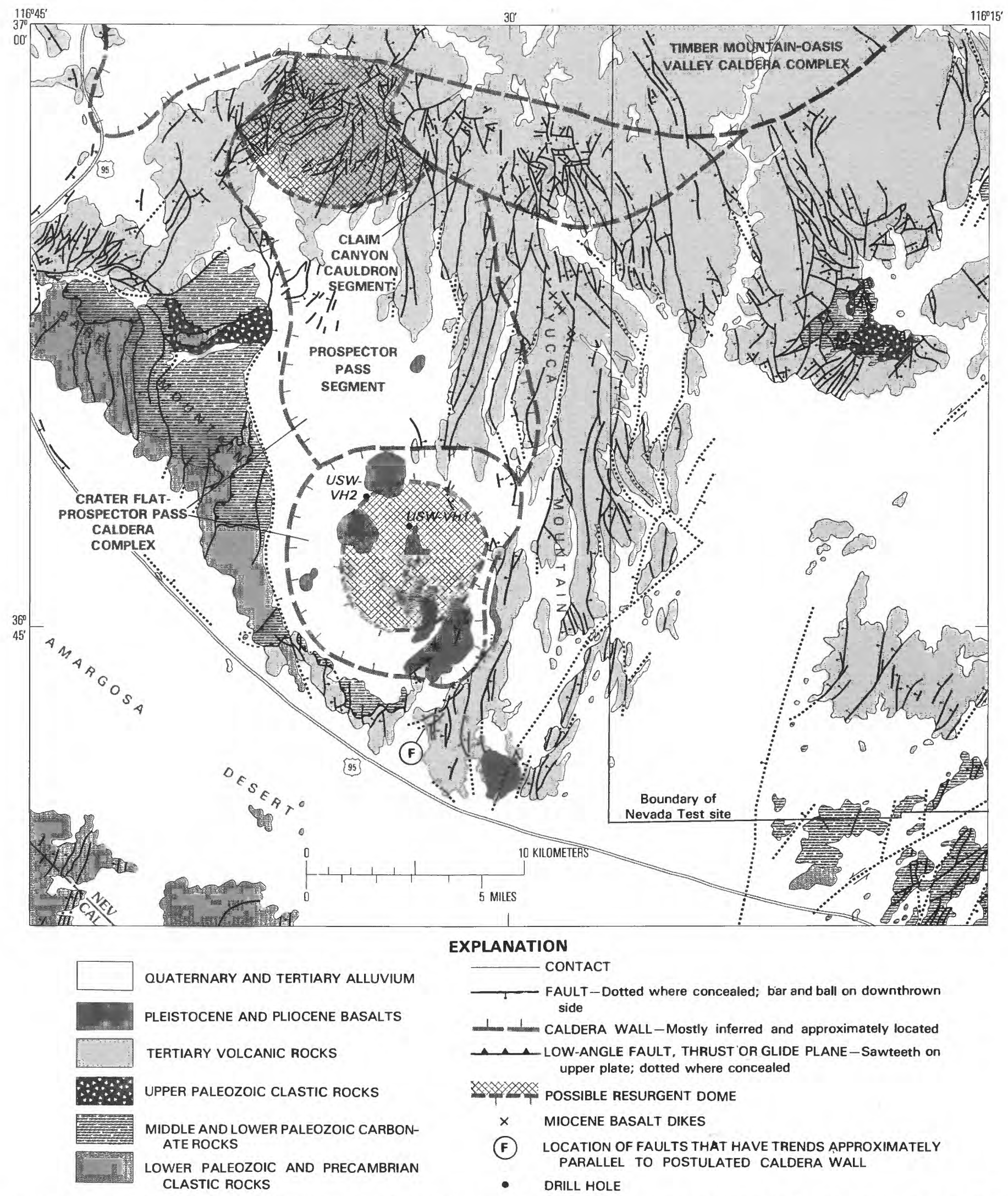

FIGURE 18.-Relation of the Crater Flat-Prospector Pass caldera complex to generalized geologic features of the southwestern Nevada Test Site region. 
Further evidence for the Tram being post-Grouse Canyon is the fact that the top of the Tram is well exposed at several places between northern Crater Flat and Beatty Wash, and no Grouse Canyon outcrops have been found between it and the other Crater Flat Tuff members. In contrast, the base of the Tram is exposed in only one tiny area in the same region.

\section{PRE-CRATER FLAT TUFF CALDERA}

Drilling at Yucca Mountain revealed a thick sequence of pre-Crater Flat tuff, including the Lithic Ridge Tuff. In addition, several lava flows possibly associated with the Lithic Ridge were penetrated by the drill holes (figs. 7, 8, and 10). As the Crater Flat Tuff shows no abrupt thickening in the area around drill holes USWG1 and USW-G2 that corresponds with a gravity low, it is unlikely that these units are within their own source area. Gravity data indicate (Snyder and Carr, 1982), however, that more than a kilometer of tuff is present in this area beneath the bottom of the drilled section. Obviously, some sort of volcano-tectonic depression exists in the northwestern Yucca Mountain area, but its origin and boundaries are largely unknown. We suggest that the north-trending, slightly arcuate fault system that lies just east of the drill holes and the NTS boundary at Yucca Mountain may be an expression of a reactivated ring-fracture zone, whose depressed area may lie somewhere to the west of this fault system (figs. 7 and 17). As there is little evidence of ash-flow tuffs older than the Lithic Ridge in the southwest NTS area, other than in the drill holes at Yucca Mountain, the volume of these older units may not have been large, and hence a well-defined caldera may not have formed. However, the abrupt westward thickening of pre-Tram dacitic lavas between drill holes USW-G1 and USW-H6 (fig. 9) suggests the possibility that the Lithic Ridge caldera could lie just to the west or northwest of Yucca Mountain, perhaps in the same general area as the Prospector Pass cauldron segments.

If the Lithic Ridge Tuff is correctly identified at Pahute Mesa (table 1), it is the only pre-Paintbrush Tuff unit known to extend well north and south of lat $37^{\circ}$ N. (fig. 10). The tuff of Yucca Flat, however, does have a distribution somewhat similar to that of the Lithic Ridge, and it is quite possible it lies below the $1,829-\mathrm{m}$ (6,000-ft) depth drilled at Yucca Mountain. If the tuff of Yucca Flat produced a caldera, it may lie north of Yucca Mountain, partly within and concealed by the younger Timber Mountain caldera complex.

\section{REFERENCES}

Byers, F. M., Jr., Carr, W. J., Christiansen, R. L., Lipman, P. W., Orkild, P. P., and Quinlivan, W. D., 1976a, Geologic map of the Timber Mountain caldera area, Nye County, Nevada: U.S. Geological Survey Miscellaneous Geologic Investigations Map I891, scale 1:48,000.

Byers, F. M., Jr., Carr, W. J., Orkild, P. P., Quinlivan, W. D., and Sargent, K. A., 1976b, Volcanic suites and related cauldrons of Timber Mountain-Oasis Valley caldera complex, southern Nevada: U.S. Geological Survey Professional Paper 919, 70 p.

Carr, W. J., 1982, Volcano-tectonic history of Crater Flat, southwestern Nevada, as suggested by new evidence from drill hole USWVH1 and vicinity: U.S. Geological Survey Open-File Report 82 $457,23 \mathrm{p}$.

Christiansen, R. L., 1979, Cooling units and composite sheets in relation to caldera structure, in Ash-flow tuffs: Geological Society of America Special Paper 180, p. 29-42.

Christiansen, R. L., Lipman, P. W., Orkild, P. P., and Byers, F. M., Jr., 1965, Structure of the Timber Mountain caldera, southern Nevada, and its relation to Basin-Range structure, in Geological Survey research 1965: U.S. Geological Survey Professional Paper 525-B, p. B43-B48.

Christiansen, R. L., Lipman, P. W., Carr, W. J., Byers, F. M., Jr., Orkild, P. P., and Sargent, K. A., 1977, The Timber Mountain-Oasis Valley caldera complex of southern Nevada: Geological Society of America Bulletin, v. 88, p. 943-959.

Crowe, B. M., and Carr, W. J., 1980, Preliminary assessment of the risk of volcanism at a proposed nuclear waste repository in the southern Great Basin: U.S. Geological Survey Open-File Report 80-357, $15 \mathrm{p}$.

Dixon, G. L., Sargent, K. A., and Carr, W. J., 1976, Abandonment of the Indian Trail Formation and distribution of certain equivalent ash-flow tuffs, eastern Nevada Test Site, in Cohee, G. V., and Wright, W. B., Changes in stratigraphic nomenclature by the U.S. Geological Survey, 1975: U.S. Geological Survey Bulletin 1422-A, p. A49-A54.

Fairer, G. M., and Townsend, D. R., 1979, Geological investigations, in U.S. Geological Survey investigations in connection with the Mighty Epic event: U.S. Geological Survey report USGS-474228, 191 p.; available only from U.S. Department of Commerce, National Technical Information Service, Springfield, VA 22161.

Gibbons, A. B., Hinrichs, E. N., Hansen, W. R., and Lemke, R. W., 1963, Geology of the Rainier Mesa quadrangle, Nye County, Nevada: U.S. Geological Survey Geologic Quadrangle Map GQ215, scale 1:24,000.

Maldonado, Florian, compiler, 1985, Geologic map of the Jackass Flats area, Nye County, Nevada: U.S. Geological Survey Miscellaneous Investigations Series Map I-1519 [in press].

Marvin, R. F., Byers, F. M., Jr., Mehnert, H. H., Orkild, P. P., and Stern, T. W., 1970, Radiometric ages and stratigraphic sequence of volcanic and plutonic rocks, southern Nye and western Lincoln Counties, Nevada: Geological Society of America Bulletin, v. 81 , p. $2657-2676$.

Noble, D. C., Sargent, K. A., Mehnert, H. H., Ekren, E. B., and Byers, F. M., Jr., 1968, Silent Canyon volcanic center, Nye County, Nevada, in Nevada Test Site: Geological Society of America Memoir 110, p. 65-75.

O'Connor, J. T., 1965, A classification for quartz-rich igneous rocks based on feldspar ratios, in Geological Survey research, 1965: U.S. Geological Survey Professional Paper 525-B, p. B79-B84. 
Orkild, P. P., 1963, Geology of the Tippipah Spring quadrangle, Nye County, Nevada: U.S. Geological Survey Geologic Quadrangle Map GQ-213, scale 1:24,000.

Orkild, P. P., Byers, F. M., Jr., Hoover, D. L., and Sargent, K. A., 1968, Subsurface geology of Silent Canyon caldera, Nevada Test Site, Nevada, in Nevada Test Site: Geological Society of America Memoir 110, p. 77-86.

Orkild, P. P., and O'Connor, J. T., 1970, Geologic map of the Topopah Spring quadrangle, Nye County, Nevada: U.S. Geological Survey Geologic Quadrangle Map GQ-849, scale 1:24,000.

Poole, F. G., Carr, W. J., and Elston, D. P., 1965, Salyer and Wahmonie Formations of southeastern Nye County, Nevada, in Cohee, G. V., and West, W. S., Changes in stratigraphic nomenclature by the U.S. Geological Survey, 1964: U.S. Geological Survey Bulletin 1224-A, p. A36-A44.

Poole, F. G., Elston, D. P., and Carr, W. J., 1965, Geologic Map of the Cane Spring quadrangle, Nye County, Nevada: U.S. Geological Survey Geologic Quadrangle Map GQ-455, scale 1:24,000.
Snyder, D. B., and Carr, W. J., 1982, Preliminary results of gravity investigations at Yucca Mountain and vicinity, southern Nye County, Nevada: U.S. Geological Survey Open-File Report 82 701, $36 \mathrm{p}$.

Spengler, R. W., Byers, F. M., Jr., and Warner, J. B., 1981, Stratigraphy and structure of volcanic rocks in drill hole USW-G1, Yucca Mountain, Nye County, Nevada: U.S. Geological Survey Open-File Report 81-1349, 50 p.

Steele, S. G., and Fairer, G. M., 1978, Geological investigations, in U.S. Geological Survey Investigations in connection with the Dining Car event, U12e.18 tunnel, Rainier Mesa, Nevada Test Site: U.S. Geological Survey report USGS-474-246 (Area 12-49), 568 p.; available only from U.S. Department of Commerce, National Technical Information Service, Springfield, VA 22161.

U.S. Geological Survey, 1978, Aeromagnetic map of Lathrop Wells area, Nevada: U.S. Geological Survey Open-File Report 78-1103. 1979, Aeromagnetic map of the Timber Mountain area, Nevada: U.S. Geological Survey Open-File Report 79-587. 